\title{
Recovery of Soil Processes in Replanted Mangroves: Implications for Soil Functions
}

\author{
Laís Coutinho Zayas Jimenez ${ }^{1}$, Hermano Melo Queiroz ${ }^{1} \oplus$, Gabriel Nuto Nóbrega ${ }^{2}$, Danilo Jefferson Romero ${ }^{1} \oplus$, \\ Youjun Deng ${ }^{3}$, Xosé Luis Otero ${ }^{4} \mathbb{D}$ and Tiago Osório Ferreira ${ }^{1, * \mathbb{C}}$ \\ 1 Department of Soil Science, Luiz de Queiroz College of Agriculture, University of São Paulo (ESALQ-USP), \\ Av. Pádua Dias 11, Piracicaba 13418-900, SP, Brazil; lais.jimenez@usp.br (L.C.Z.J.); \\ hermanomelo@usp.br (H.M.Q.); danilojromero@alumni.usp.br (D.J.R.) \\ 2 Department of Geochemistry, Graduate Program in Earth Sciences (Geochemistry), \\ Federal Fluminense University, Niterói 24020-141, RJ, Brazil; gabrielnn@id.uff.br \\ 3 Department of Soil and Crop Sciences, Texas A\&M University, College Station, TX 77843, USA; yjd@tamu.edu \\ 4 CRETUS, Department of Soil Science and Agricultural Chemistry, School of Biology, University of Santiago de \\ Compostela, 15705 Santiago de Compostela, Spain; xl.otero@usc.es \\ * Correspondence: toferreira@usp.br
}

Citation: Jimenez, L.C.Z.; Queiroz, H.M.; Nóbrega, G.N.; Romero, D.J.; Deng, Y.; Otero, X.L.; Ferreira, T.O. Recovery of Soil Processes in Replanted Mangroves: Implications for Soil Functions. Forests 2022, 13, 422. https://doi.org/10.3390/ f13030422

Academic Editor: Frank S. Gilliam

Received: 28 December 2021

Accepted: 3 March 2022

Published: 8 March 2022

Publisher's Note: MDPI stays neutral with regard to jurisdictional claims in published maps and institutional affiliations.

Copyright: (C) 2022 by the authors. Licensee MDPI, Basel, Switzerland. This article is an open access article distributed under the terms and conditions of the Creative Commons Attribution (CC BY) license (https:// creativecommons.org/licenses/by/ $4.0 /)$.

\begin{abstract}
Mangrove revegetation is a vital strategy to recover ecosystem services (e.g., climate regulation and pollutants retention) provided by these ecosystems. Although soils are directly or indirectly responsible for diverse ecosystem services in mangrove ecosystems, few studies have focused on the recovery of soil functions (e.g., carbon sequestration) after mangrove replanting. This study aimed to evaluate the recovery of soil processes associated with $\mathrm{Fe}, \mathrm{S}$, and $\mathrm{C}$ dynamics and its implications for the restoration of soil functions. Two mangrove sites under replanting initiatives were studied along the Brazilian coast (i.e., NE and SE). The study was conducted in 3- and 7-year-old replanted mangrove forests, and a comparison was made with degraded and mature mangroves. Particle size, soil C stocks, Fe forms, total Fe and S contents, degrees of pyritization of Fe, and mineralogical assemblages were assessed. Seven years after replanting, soil C stocks increased by $42 \%$ and $29 \%$ in mangrove soils from the NE and SE sites, respectively. In addition, significant increases were observed in fine particles, reactive $\mathrm{Fe}$, and pyrite contents in replanted plots. These new conditions promoted organic matter accumulation, stabilization, and potential metal retention. Our findings highlight the potential of revegetation programs for recovering soil processes and essential soil functions.
\end{abstract}

Keywords: carbon sequestration; pollutant immobilization; soil geochemistry; restoration

\section{Introduction}

Mangroves are recognized as one of the most valuable ecosystems due to their wide range of ecosystem services, whose worth is estimated at USD 24 trillion per year [1]. Among the ecosystem services provided by mangroves, those associated with soil processes (e.g., carbon sequestration and pollutant immobilization) [2-5] are currently among the most addressed. Accordingly, mangrove preservation and restoration programs that guarantee the proper functioning of their soils are vital to ensure ecosystem services $[6,7]$.

In mangrove ecosystems, the soil functions are associated with their unique geochemical conditions. These forests are subjected to daily water saturation, leading to low $\mathrm{O}_{2}$ diffusion into soil pores [8-10]. After total $\mathrm{O}_{2}$ consumption by aerobic respiration, facultative and obligate anaerobic microorganisms progressively use oxidized species $\left(\mathrm{NO}_{3}{ }^{-}\right.$, $\mathrm{Mn}^{4+}, \mathrm{Fe}^{3+}, \mathrm{SO}_{4}{ }^{2-}, \mathrm{CO}_{2}$, and $\mathrm{N}_{2}$ ) as electron acceptors for soil organic matter decomposition [11,12]. In mangrove soils, microbial-mediated reductions of $\mathrm{Fe}^{3+}$ and $\mathrm{SO}_{4}{ }^{2-}$ are the main metabolic pathways for soil organic matter decomposition [13,14]. These anaerobic 
pathways contribute to low decomposition rates and, consequently, to a high accumulation of organic matter in mangrove soils, recognized as natural carbon sinks [12,15]. Additionally, the $\mathrm{Fe}^{3+}$ and $\mathrm{SO}_{4}{ }^{2-}$ metabolic pathways release $\mathrm{Fe}^{2+}$ and sulfides, which may precipitate as pyrite, mackinawite, and acid-volatile sulfides $[14,16]$. These sulfides represent one of the most stable sinks for potentially toxic elements $[17,18]$.

In this sense, organic matter accumulation and pollutant immobilization are two key services directly controlled by the soils of mangrove forests through their unique soil biogeochemical processes $[14,19,20]$. In recent decades, the recognition of mangrove forests' relevance has stimulated the restoration of initiatives worldwide, which occurs mainly through seedling plantation [21-23]. Recent studies have reported a negative effect of short-term mangrove degradation on soil functioning [22,24,25]. Loss of soil carbon contents and increased greenhouse gas emissions are the consequences of mangrove loss and degradation [26-29]. However, to our knowledge, no studies have directly assessed the capacity of revegetation to restore natural soil processes in mangrove forests. Thus, this study aimed to assess the recovery of soil functions (e.g., sink for carbon and trace metals) and correlated ecosystem services in two mangrove forests under revegetation programs in the Brazilian northeastern and southeastern coast.

\section{Materials and Methods}

\subsection{Study Sites}

Two mangrove forests under revegetation programs were sampled along the Brazilian coast: a mangrove forest at the Guanabara Bay (Rio de Janeiro state, SE-Brazil) and another mangrove forest at the Cocó river (Ceará state, NE-Brazil; Figure 1). Plots at different stages of revegetation (i.e., 3- and 7-year-old plantations) were found at both sites, thus allowing for a temporal analysis of the effects of revegetation and their comparison with degraded plots and adjacent mature mangrove forests. The Cocó river estuary in Ceará has constituted a conservation unit of the Environmental Protection Area of Sabiaguaba since 2006. During this period, mangrove replanting initiatives have been carried out [30]. The Guanabara Bay in Rio de Janeiro is located within a Permanent Preservation Area (PPA) that covers more than 1300 ha [31]. The PPA was created in 1984 to preserve mangrove forests and support reforestation programs [31,32].

According to the time elapsed since replanting, the studied plots were divided into three categories: well-established, mature mangrove forests (RJ-MM and CE-MM), 3-yearold mangrove plantations (RJ-3Y and CE-3Y), and 7-year-old mangrove plantations (RJ-7Y and CE-7Y). Additionally, replanted and mature mangroves were compared with degraded plots within each site.

In Ceará, degraded mangrove (CE-DM) is mainly impacted by urban occupation and deforestation; thus, it is characterized by a total absence of vegetation [33]. In Rio de Janeiro, there is a long history of degradation in Guanabara Bay (e.g., deforestation, informal housing, and sewage and industrial waste disposals) [34]. Previous studies reported that degraded areas are commonly colonized by Acrostichum aureum, a typical species associated with mangrove forests in the tropics [35,36]. These plants may present vigorous growth in cleared mangrove areas and can interfere with the success of mangrove forest regeneration processes [37].

In the state of Ceará (northeastern Brazil), the climate is semi-arid (BSh, Köppen climate classification; Table 1), with mean annual precipitation under $900 \mathrm{~mm}$ and with well-defined rainy (February to May) and dry (June to January) seasons [38,39]. Mangrove forests are surrounded by dunes and by the sandy-clayey soils from the Barreiras geological formation, dominated by quartz and kaolinite, with minor amounts of Fe oxyhydroxides [40-42]. Mangrove soils are subjected to a daily mesotidal regime, ranging from 0.75 to $3.25 \mathrm{~m}$ (Table 1) [43], with redox potentials (Eh) ranging between +16 and $+450 \mathrm{mV}$ and $\mathrm{pH}$ values ranging from 6.3 to 7.7 (Table 1). Mature mangroves are composed of Avicennia germinans (L.) L., Laguncularia racemosa (L.) C. F., and Rhizophora mangle L. Revegetation was carried out using Rhizophora mangle L propagules. 


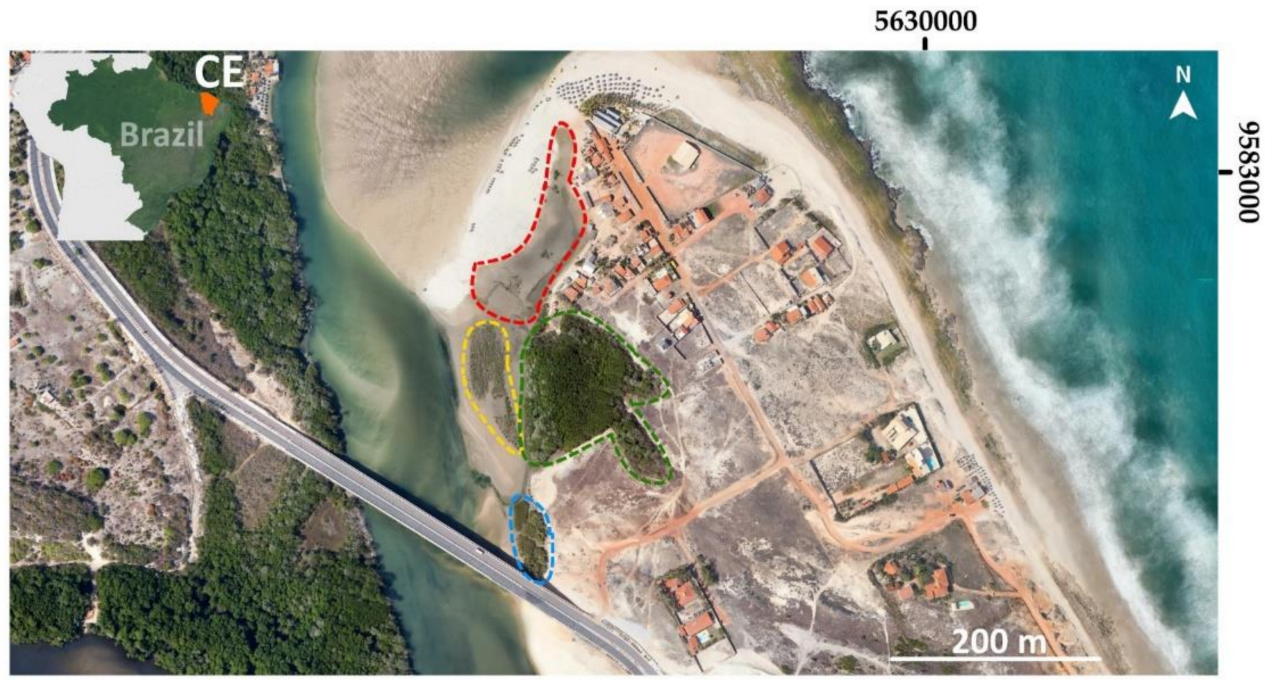

(a)

\section{Mature mangrove \\ 7-year-old mangrove plantation \\ 3-year-old mangrove plantation Degraded mangrove}

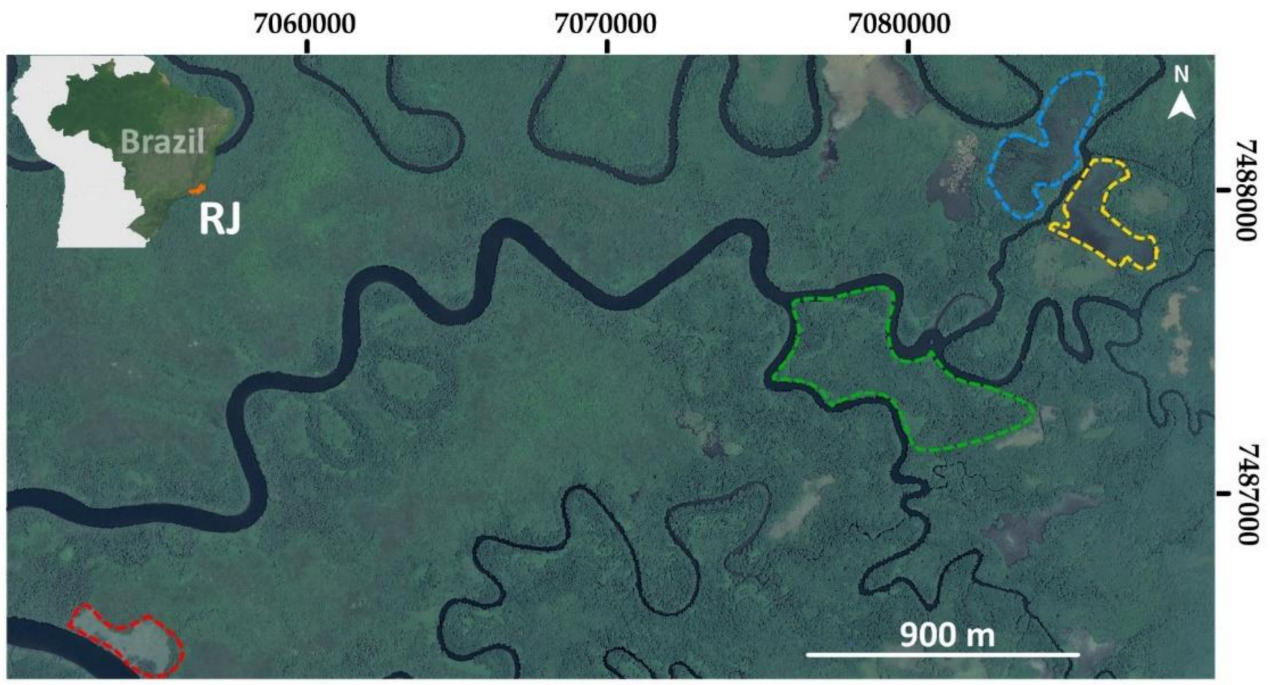

(b)

Figure 1. Location of the studied mangrove forests in Ceará (NE-Brazil) (a) and Rio de Janeiro (SE-Brazil) (b). Different colored plots indicate the different studied scenarios, i.e., degraded and mature mangrove forests and plots at different stages of revegetation (3- and 7-year-old plantations). Satellite images were obtained with Google Earth Pro $^{\mathrm{TM}}$.

The climate in Guanabara Bay (southeastern Brazil) is classified as tropical humid (Af, Köppen climate classification; Table 1), with a rainfall regime varying between 1100 and $2100 \mathrm{~mm}$, well-distributed throughout the year. Granitic-gneissic rocks from the Serra do Mar outcrop surround the Guanabara Bay, showing clayey soils composed of large amounts of gibbsite, kaolinite, and Fe oxyhydroxides in the clay fraction [44]. The region has low hydrodynamic activity, with a semidiurnal microtidal regime ranging from 0.1 to $1.2 \mathrm{~m}$ (Table 1) [45]. Mangrove soils are marked by Eh values ranging between +250 and $+408 \mathrm{mV}$ and $\mathrm{pH}$ values close to neutrality (ranging from 6.9 to 7.3; Table 1). The predominant plant species in mature and replanted mangrove forests are Avicennia germinans (L.) L., Laguncularia racemosa (L.) C. F., and Rhizophora mangle L. 
Table 1. Location, geoclimatic and physicochemical ( $\mathrm{pH}$ and $\mathrm{Eh}$ ) characteristics, tidal regime, and forest structure of studied mangrove forests from each plot.

\begin{tabular}{|c|c|c|c|c|c|c|c|}
\hline Plot & $\begin{array}{l}\text { Location } \\
\text { (UTM) }\end{array}$ & Climate* & $\begin{array}{c}\text { Geological } \\
\text { Surroundings }\end{array}$ & Eh & $\mathrm{pH}$ & Tidal Regime & Forest Features \\
\hline \multicolumn{8}{|c|}{ Ceará } \\
\hline $\mathrm{DM}$ & $\begin{array}{c}562,638.15 \mathrm{~m} \mathrm{E} \\
9,582,935.79 \mathrm{~m} \mathrm{~S}\end{array}$ & BSh & $\begin{array}{l}\text { Sedimentary } \\
\text { deposists }\end{array}$ & $+425 \pm 28 \mathrm{mV}$ & $7.0 \pm 0.2$ & $\begin{array}{c}\text { Mesotidal } \\
(0.75 \text { to } 3.25 \mathrm{~m})\end{array}$ & No vegetation \\
\hline $3 Y$ & $\begin{array}{c}562,577.33 \mathrm{~m} \mathrm{E} \\
9,582,811.95 \mathrm{~m} \mathrm{~S}\end{array}$ & BSh & $\begin{array}{l}\text { Sedimentary } \\
\text { deposits }\end{array}$ & $+450 \pm 16 \mathrm{mV}$ & $7.0 \pm 0.1$ & $\begin{array}{c}\text { Mesotidal } \\
(0.75 \text { to } 3.25 \mathrm{~m})\end{array}$ & $\mathrm{RM}$ \\
\hline $7 Y$ & $\begin{array}{c}562,624.41 \mathrm{~m} \mathrm{E} \\
9,582,661.79 \mathrm{~m} \mathrm{~S}\end{array}$ & BSh & $\begin{array}{l}\text { Sedimentary } \\
\text { deposists }\end{array}$ & $+437 \pm 22 \mathrm{mV}$ & $7.7 \pm 0.3$ & $\begin{array}{c}\text { Mesotidal } \\
(0.75 \text { to } 3.25 \mathrm{~m})\end{array}$ & $\mathrm{RM}$ \\
\hline $\mathrm{MM}$ & $\begin{array}{c}562,669.31 \mathrm{~m} \mathrm{E} \\
9,582,785.29 \mathrm{~m} \mathrm{~S}\end{array}$ & BSh & $\begin{array}{l}\text { Sedimentary } \\
\text { deposists }\end{array}$ & $+21 \pm 163 \mathrm{mV}$ & $6.3 \pm 0.1$ & $\begin{array}{c}\text { Mesotidal } \\
(0.75 \text { to } 3.25 \mathrm{~m})\end{array}$ & AG, LR, and RM. \\
\hline $\mathrm{DM}$ & $\begin{array}{c}705,619.57 \mathrm{~m} \mathrm{E} \\
7,486,388.30 \mathrm{~m} \mathrm{~S}\end{array}$ & Af & $\begin{array}{c}\text { Granitic-gneissic } \\
\text { rocks }\end{array}$ & $\begin{array}{l}\text { Rio de Janeiro } \\
+250 \pm 25 \mathrm{mV}\end{array}$ & $6.9 \pm 0.2$ & $\begin{array}{c}\text { Microtidal } \\
(0.1 \text { to } 1.2 \mathrm{~m})\end{array}$ & AG, LR, and RM. \\
\hline $3 Y$ & $\begin{array}{c}708,610.57 \mathrm{~m} \mathrm{E} \\
7,487,890.50 \mathrm{~m} \mathrm{~S}\end{array}$ & Af & $\begin{array}{c}\text { Granitic-gneissic } \\
\text { rocks }\end{array}$ & $+340 \pm 53 \mathrm{mV}$ & $6.9 \pm 0.1$ & $\begin{array}{l}\text { Microtidal } \\
\text { (0.1 to } 1.2 \mathrm{~m})\end{array}$ & AG, LR, and RM. \\
\hline $7 Y$ & $\begin{array}{c}708,487.00 \mathrm{~m} \mathrm{E} \\
7,488,109.00 \mathrm{~m} \mathrm{~S}\end{array}$ & Af & $\begin{array}{c}\text { Granitic-gneissic } \\
\text { rocks }\end{array}$ & $+408 \pm 147 \mathrm{mV}$ & $7.3 \pm 0.3$ & $\begin{array}{l}\text { Microtidal } \\
\text { (0.1 to } 1.2 \mathrm{~m})\end{array}$ & AG, LR, and RM. \\
\hline MM & $\begin{array}{c}707,915.30 \mathrm{~m} \mathrm{E} \\
7,487,394.68 \mathrm{~m} \mathrm{~S}\end{array}$ & Af & $\begin{array}{l}\text { Granitic-gneissic } \\
\text { rocks }\end{array}$ & $+424 \pm 197 \mathrm{mV}$ & $7.2 \pm 0.2$ & $\begin{array}{l}\text { Microtidal } \\
\text { (0.1 to } 1.2 \mathrm{~m})\end{array}$ & AG, LR, and RM. \\
\hline
\end{tabular}

* According to Köppen climate classification. DM: degraded mangrove. 3Y: 3-year-old mangrove. 7Y: 7-year-old mangrove. MM: mature mangrove forests. BSh: semi-arid. Af: tropical humid. Avicennia germinans (L.) L.: AG. Laguncularia racemosa (L.) C. F.: LR. Rhizophora mangle L: RM.

\subsection{Soil Sampling}

Within both coastal sites, soil samples were collected from plots at different stages of vegetative growth (3- and 7-year-old plantations), degraded, and mature mangrove forests (Figure 1). In both sites, soil sampling was carried out during low tide within $1 \times 1 \mathrm{~m}$ sampling points within each study plot, using polyvinyl chloride tubes attached to a stainless-steel sampler for flooded soils in order to obtain undeformed soil samples. After sample collection, tubes were hermetically sealed and transported to the laboratory in vertical position under refrigerated conditions; all soil samples were removed from the tubes and divided into sections at the following depth intervals: 0-10, 10-20, 20-30, and $30-40 \mathrm{~cm}$.

Redox potential (Eh) and $\mathrm{pH}$ were measured in the field using portable meters. Eh was determined using a platinum electrode, and the final readings were corrected to a calomel reference electrode $(+244 \mathrm{mV})$. $\mathrm{pH}$ values were measured using a glass electrode calibrated with standard solutions ( $\mathrm{pH} 4.0$ and 7.0).

\subsection{Soil Chemical and Physical Analyses}

Particle size distribution was determined by the densimeter method after both mechanical dispersion (agitation for $12 \mathrm{~h}$ ) and chemical dispersion using a $0.15 \mathrm{~mol} \mathrm{~L}^{-1}$ sodium hexametaphosphate and $1 \mathrm{~mol} \mathrm{~L}^{-1}$ sodium hydroxide solution [46]. Before analysis, samples were pretreated with hydrogen peroxide ( $30 \%$ solution) to remove soil organic matter.

Soil organic carbon (OC) was determined by dry combustion in an elemental analyzer (LECO SE-144 DR). Prior to analysis, all soil samples were treated with $\mathrm{HCl} \mathrm{mol} \mathrm{\textrm {L } ^ { - 1 }}$ for carbonate removal [47]. Soil carbon stocks (SCS) were quantified to a depth of $40 \mathrm{~cm}$ following Equation (1) [47]:

$$
\text { SCS }=\text { soil bulk density } \times \text { depth } \times \text { OC }
$$

Solid-phase Fe partitioning was performed to assess the recovery of soil processes associated with Fe and S dynamics in the studied mangrove soils $[48,49]$. This method has 
been largely used in mangrove soil studies $[14,17,39,50]$ and allows the obtainment of six distinct, operationally defined Fe fractions:

1. F1—exchangeable and soluble $\mathrm{Fe}$, extracted by $1 \mathrm{~mol} \mathrm{~L}^{-1} \mathrm{MgCl}_{2}$ solution at $\mathrm{pH}$ 7, agitated for $30 \mathrm{~min}$;

2. F2 - carbonate-associated $\mathrm{Fe}$, extracted by $1 \mathrm{~mol} \mathrm{~L}^{-1} \mathrm{NaOAC}$ solution at $\mathrm{pH} 5$ (adjusted using acetic acid), agitated for $5 \mathrm{~h}$;

3. F3-Fe in ferrihydrite, extracted by $0.04 \mathrm{~mol} \mathrm{~L}^{-1}$ hydroxylamine $+25 \%$ acetic acid $(v / v)$ solution at $30^{\circ} \mathrm{C}$, agitated for $6 \mathrm{~h}$;

4. $\quad$ F4-Fe in lepidocrocite, extracted by a $0.04 \mathrm{~mol} \mathrm{~L}^{-1}$ hydroxylamine $+25 \%$ acetic acid $(v / v)$ solution at $96^{\circ} \mathrm{C}$, agitated for $6 \mathrm{~h}$;

5. F5-Fe in crystalline oxyhydroxides, extracted by a $0.25 \mathrm{~mol} \mathrm{~L}^{-1} \mathrm{Na}_{3} \mathrm{C}_{6} \mathrm{H}_{5} \mathrm{O}_{7}$ (sodium citrate) $+0.11 \mathrm{~mol} \mathrm{~L}^{-1} \mathrm{NaHCO}_{3}$ (sodium bicarbonate) and $3 \mathrm{~g} \mathrm{Na}_{2} \mathrm{~S}_{2} \mathrm{O}_{4}$ (sodium dithionite) solution at $75^{\circ} \mathrm{C}$, agitated for $30 \mathrm{~min}$;

6. F6-Fe in pyritic forms (extracted after previous removal of silicates using $10 \mathrm{~mol} \mathrm{~L}^{-1}$ hydrofluoric acid, followed by agitation for $16 \mathrm{~h}$ and removal of organic matter using concentrated sulfuric acid, agitated for $2 \mathrm{~h}$ ), using a concentrated nitric acid solution.

Between each step and the next, samples were centrifuged (6000 RPM for $30 \mathrm{~min}$ ) to separate the extract, then washed with ultrapure water and centrifuged again.

Following the determination of pyritic Fe, the degree of Fe pyritization was calculated (DOP; Equation (2)), which determines the portion of the pseudo-total Fe content (i.e., the sum of F1 to F6) that is incorporated into pyrite (F6) (Berner, 1970; Ferreira et al., 2007). In addition, the sum of $\mathrm{F} 1$ to $\mathrm{F} 5$ was considered as reactive $\mathrm{Fe}$.

$$
\mathrm{DOP}=[\mathrm{F} 6 /(\Sigma \mathrm{F} 1 \rightarrow \mathrm{F} 6)] \times 100
$$

Moreover, total Fe and total $\mathrm{S}$ were determined by $\mathrm{X}$-ray fluorescence spectrometry (XRF). Prior to analysis, all samples were dried at $105^{\circ} \mathrm{C}$ and finely ground using an agate mill.

\subsection{Mineralogical Characterization by X-ray Diffraction (XRD) and Scanning Electron Microscopy (SEM)}

Mineralogical composition was assessed by X-ray diffraction (XRD) analysis using a Rigaku Miniflex II with $\mathrm{CuK} \alpha$ radiation. XRD analysis was carried out using nonoriented powder samples (i.e., bulk samples) scanned from 3 to $60^{\circ} 2 \theta$, at $0.02^{\circ} 2 \theta$ step size and 3 s step ${ }^{-1}$ count time. To remove organic matter, soil samples were previously treated with $9 \%$ sodium hypochlorite [51].

Scanning electron microscopy was used to obtain photomicrographs of soil minerals. All images were obtained using a SU8010 cold-field emission scanning electron microscope (FESEM, Hitachi, Japan) equipped with energy-dispersive X-ray spectroscopy (EDS, AMETEK-EDAX, Mahwah, NJ, USA) for elemental analysis.

\subsection{Statistical Analysis}

A nonparametric statistical test with a 5\% significance level was carried out to assess differences in soil parameters among the different scenarios (i.e., 3- and 7-year-old, degraded, and mature mangrove forests) within both sites (Ceará and Rio de Janeiro). As each study site is subjected to contrasting climate and geological surroundings, statistical analyses were performed independently. Relationships among soil parameters were assessed by multivariate discriminant analysis [52], which contributed to identifying the main variables that distinguish stages of revegetation and allowed us to make inferences on the recovery of soil processes. All statistical tests were performed using the XLSTAT software version v.2014.5.03. 


\section{Results}

\subsection{Particle Size Distribution}

Soils from the CE site were dominated by sand and were predominantly classified as having a sandy-loam texture (CE-7Y, sand: $63 \%$, silt: $29 \%$, and clay $8 \%$; CE-3Y, sand: $65 \%$, silt: $27 \%$, and clay $8 \%$; CE-DM, sand: $68 \%$, silt: $25 \%$, and clay $7 \%$ ), except for CE-MM (sand: $29 \%$, silt: $52 \%$, and clay $19 \%$; Figure $2 a$ ), which showed a loam texture. On the other hand, soils from the RJ site showed a higher presence of fine particles with a silty-clay texture in RJ-MM (sand: $\%$, silt: $43 \%$, and clay 56\%), RJ-7Y (sand: 5\%, silt: $49 \%$, and clay $46 \%$ ), and RJ-DM (sand: $6 \%$, silt: 51\%, and clay $44 \%$ ), and a silty-clay-loam texture in RJ-3Y (sand: $4 \%$, silt: $48 \%$, and clay $49 \%$; Figure 2 b).

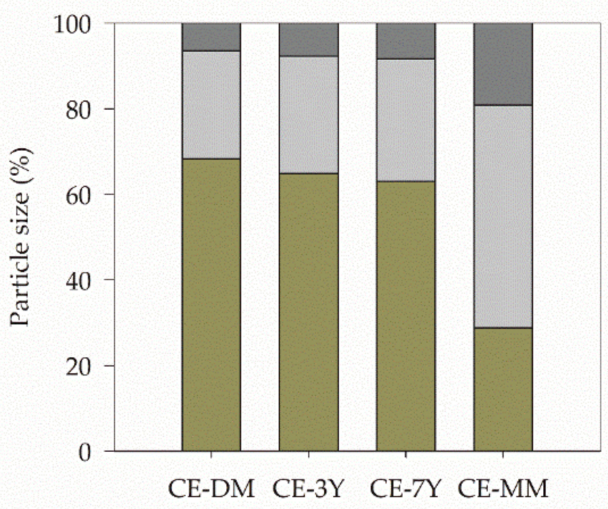

(a)

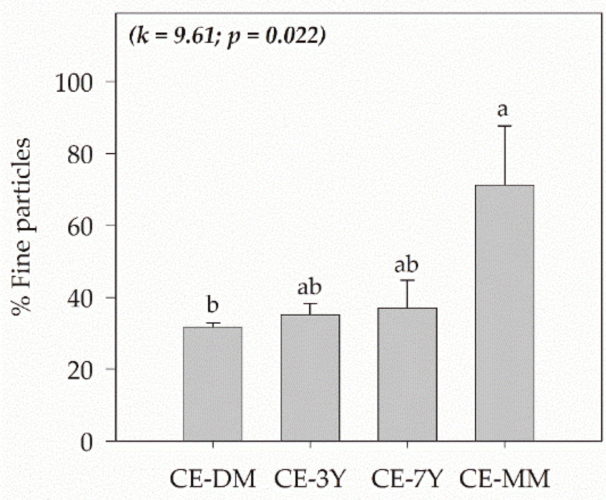

(c)

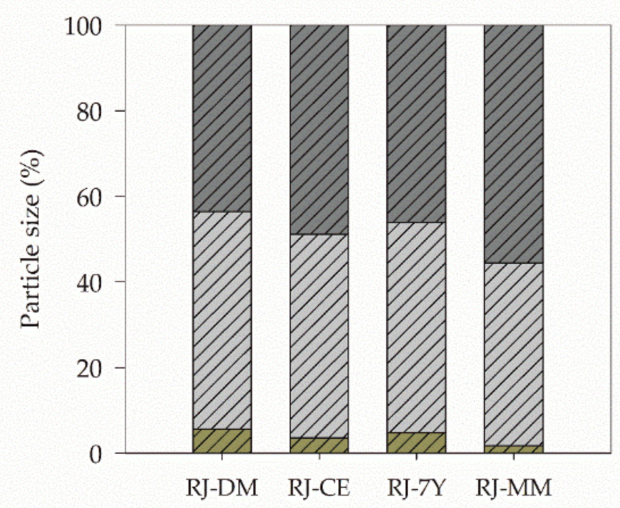

(b)

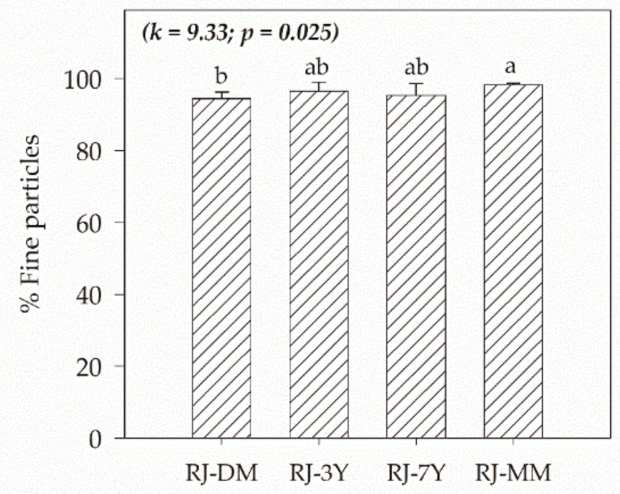

(d)

Figure 2. Particle size distribution in mature mangroves, degraded plots, and 3- and 7-year-old plantations in Ceará (a) and Rio de Janeiro (b). (c) Fine particle (silt + clay) contents in degraded, mature, and replanted mangrove forests from the Ceará and (d) Rio de Janeiro sites. Different lowercase letters indicate significant differences among fine particle contents found by the Kruskal-Wallis test at the $5 \%$ probability level, and $\mathrm{k}$ values above the critical $\mathrm{k}(7.8147)$ indicate statistical differences.

In addition, in both sites (Figure 2c,d), there was a significant increase in fine particle (silt + clay) contents in replanted (3- and 7-year-old) plots in comparison with degraded mangroves. In CE-DM, CE-3Y, CE-7Y, and CE-MM, fine particle contents were $32 \pm 1 \%$, $35 \pm 3 \%, 37 \pm 8 \%$, and $71 \pm 16 \%$, respectively (Figure $2 \mathrm{c}$ ). In the Rio de Janeiro site, fine particle contents in RJ-DM, RJ-3Y, RJ-7Y, and RJ-MM were $94 \pm 2 \%, 96 \pm 3 \%, 95 \pm 3 \%$, and $98 \pm 0.1 \%$, respectively (Figure $2 \mathrm{~d}$ ).

\subsection{Soil Carbon Stocks}

In the Ceará site, mean SCS values were significantly higher $(\mathrm{k}=23.48 ; p<0.001)$ in mature (CE-MM: $20.2 \pm 6.4 \mathrm{Kg} \mathrm{m}^{-2}$ ) than in replanted mangroves (CE-7Y: $11.5 \pm 3.1 \mathrm{Kg} \mathrm{m}^{-2}$; 
CE-3Y: $10.5 \pm 4.9 \mathrm{Kg} \mathrm{m}^{-2}$ ) and in degraded plots (CE-DM: $6.1 \pm 1.7 \mathrm{Kg} \mathrm{m}^{-2}$; Figure 3a). No significant differences were observed between the replanted plots (CE-3Y and CE-7Y), while significantly lower SCS values were observed in CE-DM (Figure 3a).

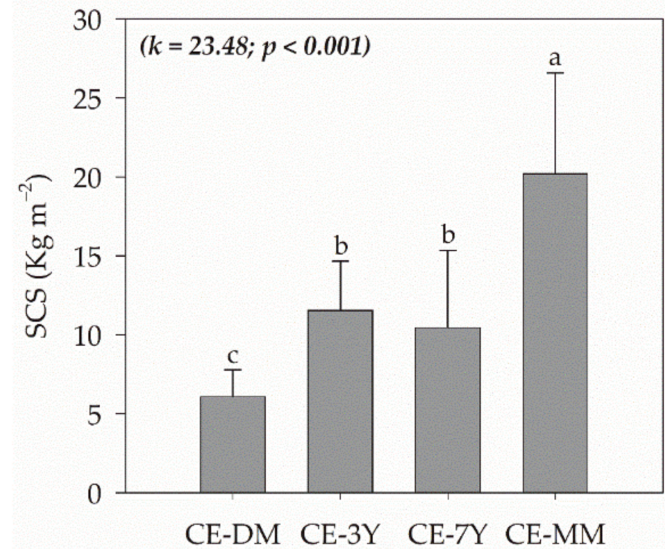

(a)

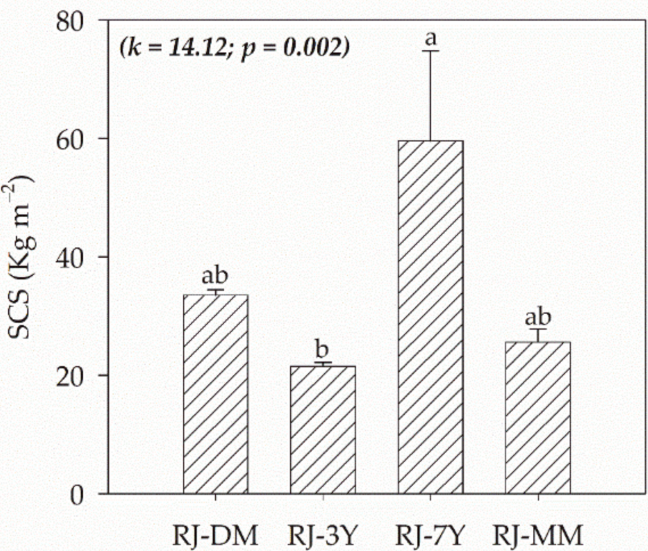

(b)

Figure 3. Soil carbon stocks for the different stages of revegetation (DM; 3Y; 7Y; MM) in the Ceará (a) and Rio de Janeiro (b) mangrove forests. Different lowercase letters indicate significant differences among variables found by the Kruskal-Wallis test at the $5 \%$ probability level, and $\mathrm{k}$ values above the critical $\mathrm{k}$ (7.8147) indicate statistical differences.

In Rio de Janeiro, significantly higher SCS values $(\mathrm{k}=14.12 ; p=0.002)$ were observed in RJ-7Y $\left(59.6 \pm 15.2 \mathrm{Kg} \mathrm{m}^{-2}\right)$, while the lowest values were found in RJ-3Y $\left(21.5 \pm 0.6 \mathrm{Kg} \mathrm{m}^{-2}\right.$; Figure 3b). In RJ-DM and RJ-MM, SCS values were $33.5 \pm 0.9$ and $25.6 \pm 2.2 \mathrm{Kg} \mathrm{m}^{-2}$, respectively (Figure $3 b$ ).

\subsection{Fe Partitioning and Total Contents of Fe and $S$}

In the Ceará site, sequential extraction showed a predominance of Fe associated with oxyhydroxides (i.e., F3, F4, and F5) in all plots (Figure 4a). Most Fe was associated with lowcrystallinity fractions (i.e., F3 and F4), especially in both replanted plots. Contrastingly, in CE-MM, there was a sharp increase in Fe associated with the pyritic fraction compared with degraded and replanted plots. Regarding DOP values, the highest values were observed in CE-MM $(42.8 \pm 22.9 \%)$, but no significant differences were observed between CE-DM $(0.8 \pm 0.3 \%)$, CE-3Y $(1.0 \pm 0.2 \%)$, and CE-7Y $(1.8 \pm 2.1 \%$; Figure $4 \mathrm{c})$.

In the Rio de Janeiro site, in RJ-DM and RJ-3Y, sequential extraction showed a dominance of Fe associated with both low- and high-crystallinity Fe oxyhydroxides (i.e., F3, F4, and F5) and a sharp increase in Fe associated with pyrite (i.e., F6) with revegetation (Figure 4b). In RJ-7Y, the content of pyritic Fe $\left(74,300 \pm 60,130 \mathrm{mg} \mathrm{kg}^{-1}\right)$ was $\sim 4$-fold higher than in RJ-DM ( $\left.8500 \pm 4800 \mathrm{mg} \mathrm{kg}^{-1}\right)$ and 2-fold higher than in RJ-3Y (see Figure $\left.4 \mathrm{~b}\right)$. DOP values in all RJ plots ranged from $37 \%$ to $61 \%$, and no significant differences were observed between plots (Figure 4d).

Regarding total Fe and S content, in the Ceará site, mean Fe contents were significantly higher in replanted plots (CE-MM: 19,700 \pm 10,800 mg kg-1; CE-3Y: $7120 \pm 6800 \mathrm{mg} \mathrm{kg}^{-1}$; CE-7Y: $4900 \pm 1700 \mathrm{mg} \mathrm{kg}^{-1}$ ) compared with the degraded plot (CE-DM: $2000 \pm 830 \mathrm{mg} \mathrm{kg}^{-1}$; Figure 5a). On the other hand, mean total S content in CE-MM $\left(9200 \pm 1300 \mathrm{mg} \mathrm{kg}^{-1}\right)$ was significantly higher than those in replanted and degraded mangroves, and no significant differences were observed among CE-3Y, CE-7Y, and CE-DM (Figure 5a). 


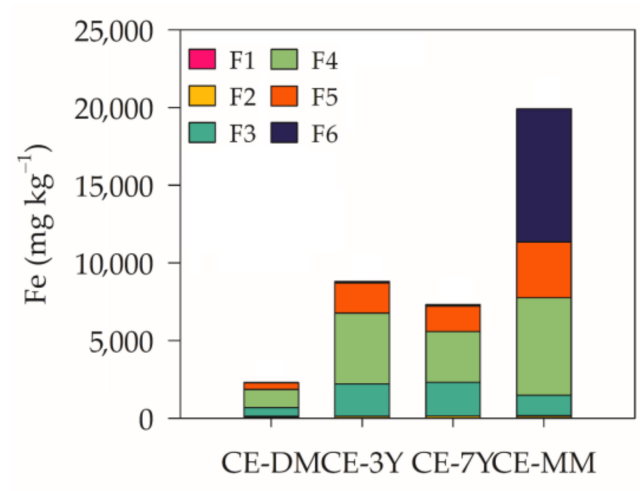

(a)

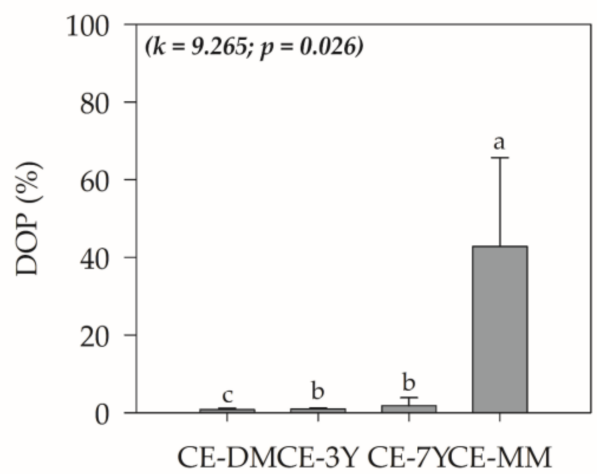

(c)

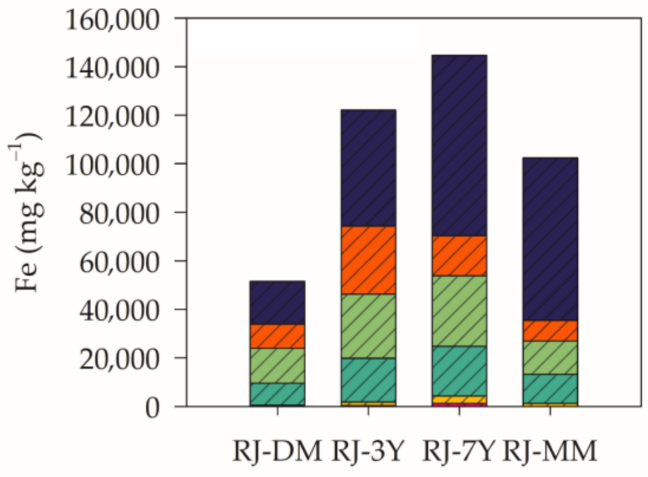

(b)

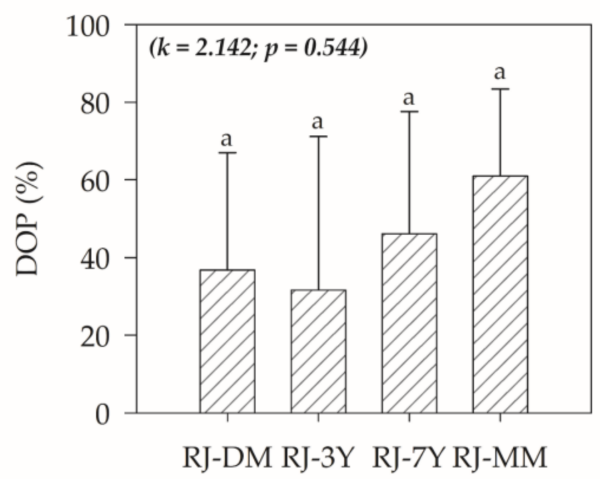

(d)

Figure 4. Fe partitioning (a,b) and degree of Fe pyritization, DOP $(\mathbf{c}, \mathbf{d})$ in all studied plots. Different lowercase letters indicate significant differences among variables found by the Kruskal-Wallis test at the $5 \%$ probability level, and $\mathrm{k}$ values above the critical $\mathrm{k}(7.8147)$ indicate statistical differences.

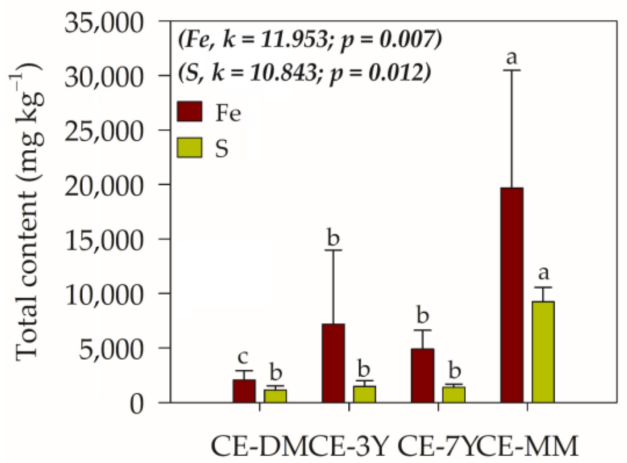

(a)

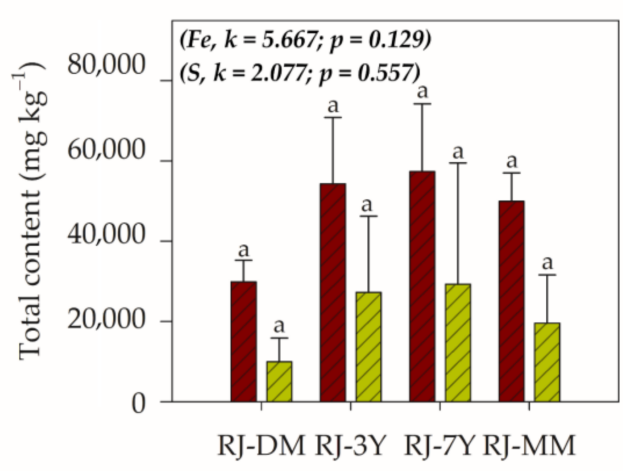

(b)

Figure 5. Total Fe and S contents in all studied plots in Ceará (a) and Rio de Janeiro (b). Different lowercase letters indicate significant differences among variables found by the Kruskal-Wallis test at the $5 \%$ probability level, and $\mathrm{k}$ values above the critical $\mathrm{k}(7.8147)$ indicate statistical differences.

In the Rio de Janeiro coastal site, no significant differences were observed regarding total Fe and $\mathrm{S}$ contents among the studied plots (Figure 5a). Mean total Fe content in Rio de Janeiro ranged from $30,000 \pm 5400 \mathrm{mg} \mathrm{kg}^{-1}$ in RJ-DM to $57,400 \pm 16,900 \mathrm{mg} \mathrm{kg}^{-1}$ in RJ-7Y (Figure 5b). Total S contents varied between 10,000 \pm 5900 (RJ-DM) and 29,300 $\pm 30,200 \mathrm{mg} \mathrm{kg}^{-1}$ (RJ-7Y; Figure 5b). 


\subsection{Mineralogical Characteristics (XRD and SEM Analyses)}

The XRD diffractograms indicated that the mineralogical assemblage in mangrove soils from Ceará was mainly composed of quartz, whereas mangrove soils from Rio de Janeiro were mainly composed of quartz and kaolinite (Figure 6).

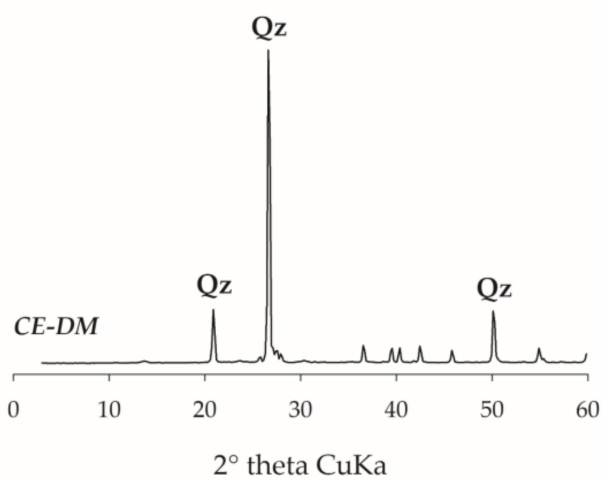

(a)

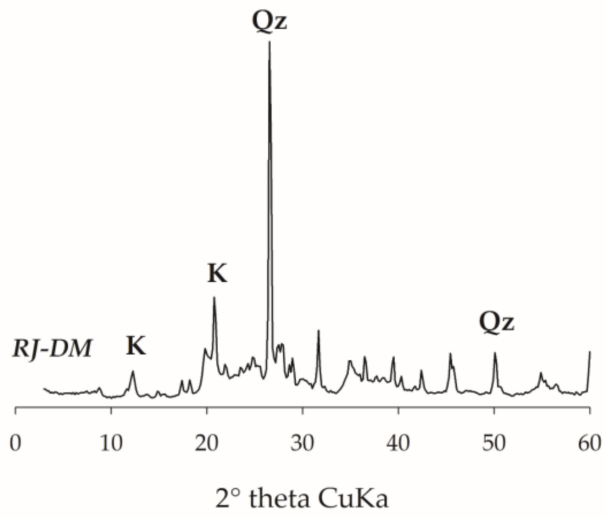

(c)

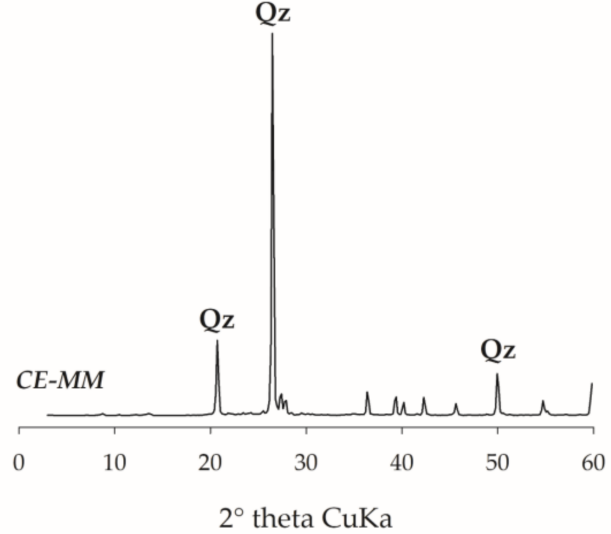

(b)

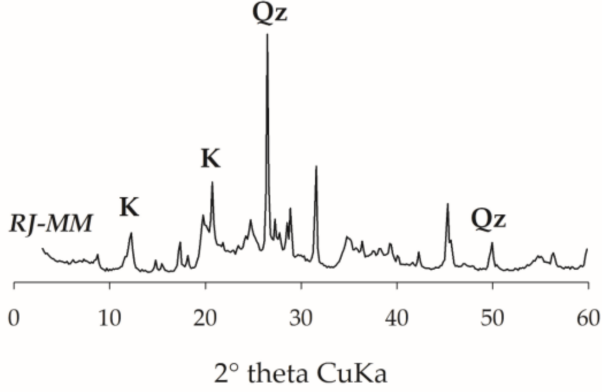

(d)

Figure 6. XRD data of nonoriented soil samples from both degraded and mature mangroves in the Ceará $(\mathbf{a}, \mathbf{b})$ and Rio de Janeiro (c,d) sites. Qz: quartz, K: kaolinite.

SEM micrographs of mangrove soils from Ceará revealed arrangements of poorly crystalline isolated microcrystals of authigenic euhedral pyrites in the replanted plots (represented by CE-7Y; Figure 7a). On the other hand, in the mature mangrove (CE-MM), authigenic framboidal pyrites were densely packed and homogeneous. Furthermore, the EDS spectra corroborated the presence of pyrite with chemical signals from Fe and $S$ (Figure 7c,d).

In the Rio de Janeiro site, in RJ-MM, SEM micrographs showed the presence of smooth spherical authigenic pyrite framboids (Figure 8a) along with irregularly shaped kaolinite particles (Figure 8b). The SEM-EDS analysis corroborated this mineralogical assemblage by elemental composition (Fe, S, Si, O, Al, and K; Figure 8c-e). 


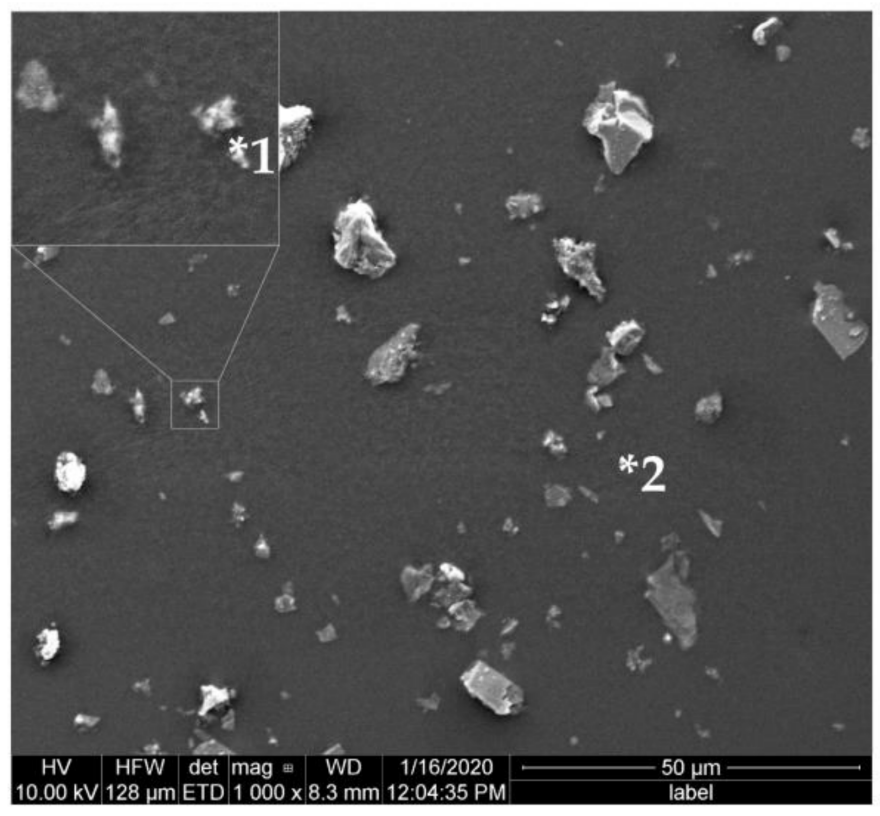

(a)

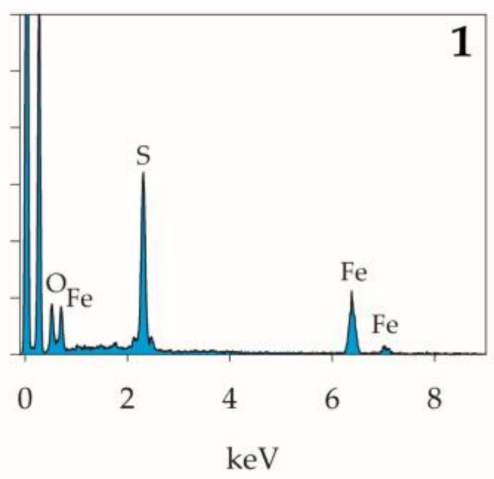

(c)

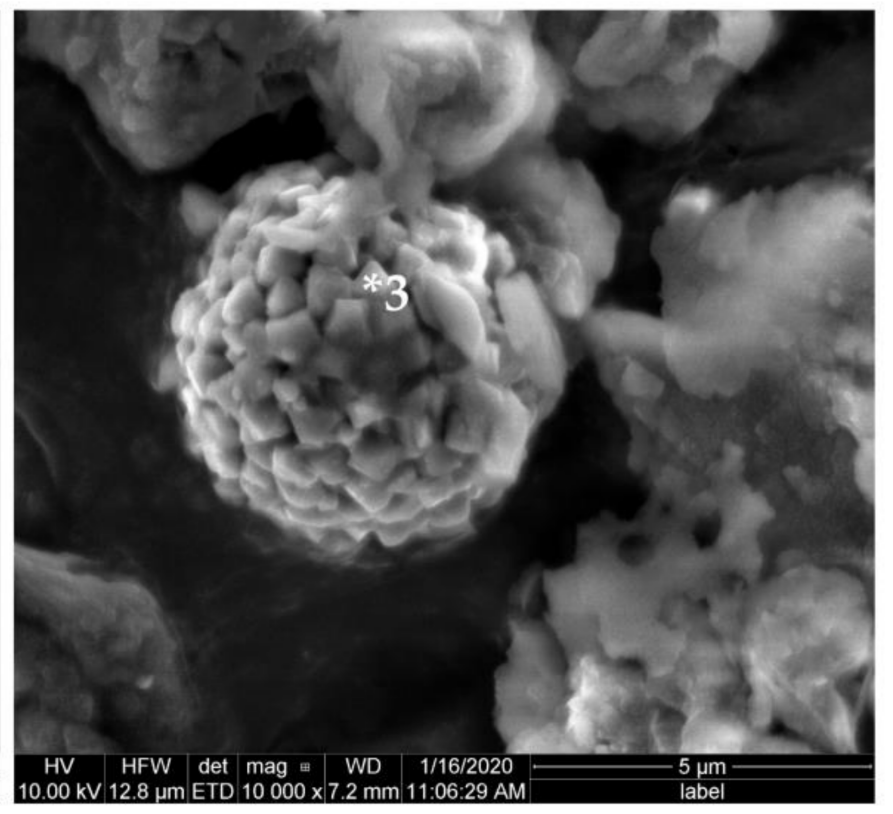

(b)

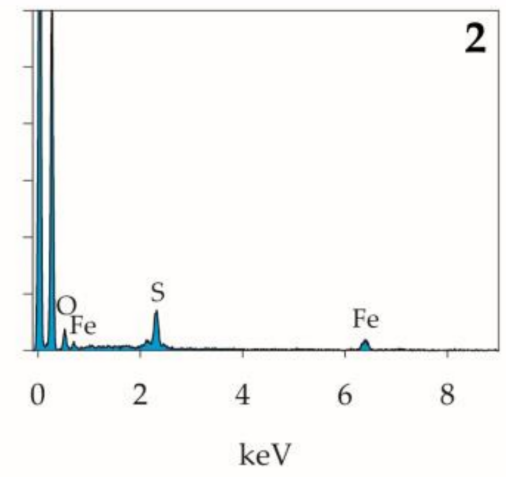

(d)

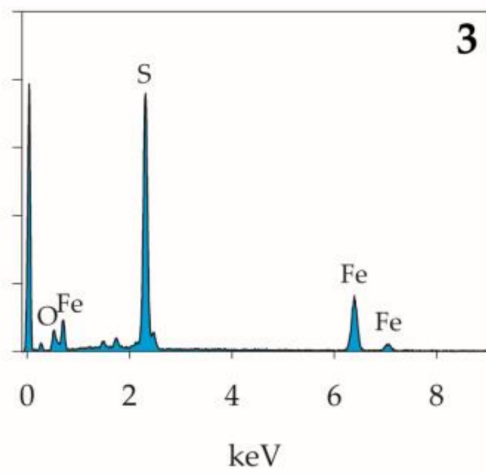

(e)

Figure 7. SEM photomicrographs of pyrites found in mangrove soils from CE-7Y (* represents the exact surface from where the EDS spectra were obtained) (a) and CE-MM (b) and their corresponding EDS spectra (c-e). In CE-7Y (a), the SEM-EDS photomicrographs revealed arrangements of poorly crystalline isolated authigenic euhedral pyrites. Contrastingly, in CE-MM, the SEM-EDS photomicrographs revealed the presence of authigenic framboidal pyrites.

\subsection{Discriminant Analysis}

The discriminant analysis revealed contrasting effects of revegetation in the study sites (Figure 9). In Ceará, there was an increase in SCS, DOP, fine particles (silt and clay), and $S$ and Fe contents in mature and replanted mangrove plots (Figure 9a,b). In fact, these variables explained $81.91 \%$ of data variance, while Eh values and pyritic Fe explained only $12.80 \%$. Conversely, in Rio de Janeiro, no apparent effects of revegetation were observed (Figure 9c,d). Nevertheless, the pyritic Fe, SCS, and DOP vectors in data from RJ-7Y indicated a higher value of these parameters in this plot than in others. 


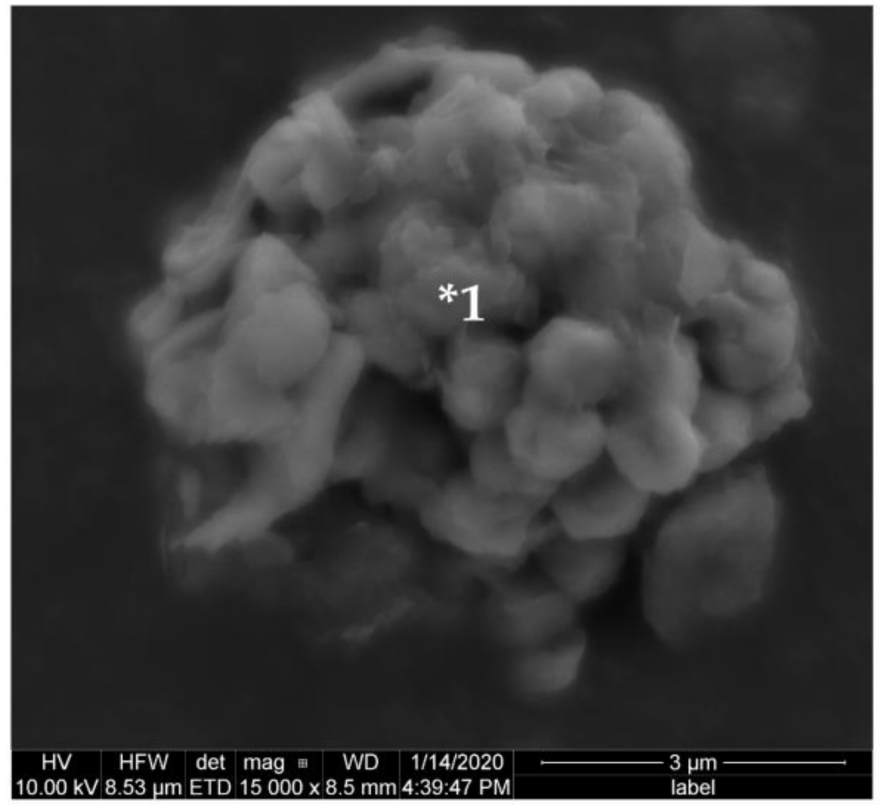

(a)

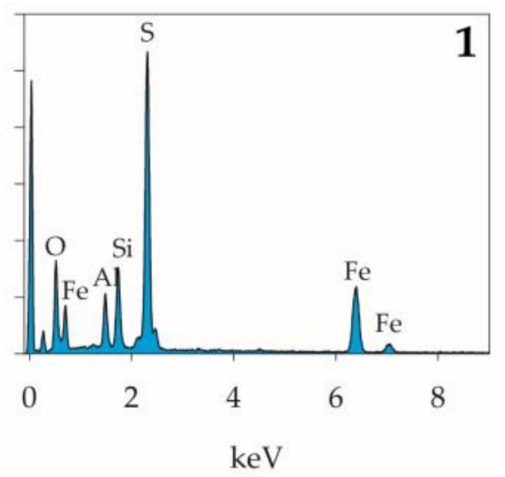

(c)

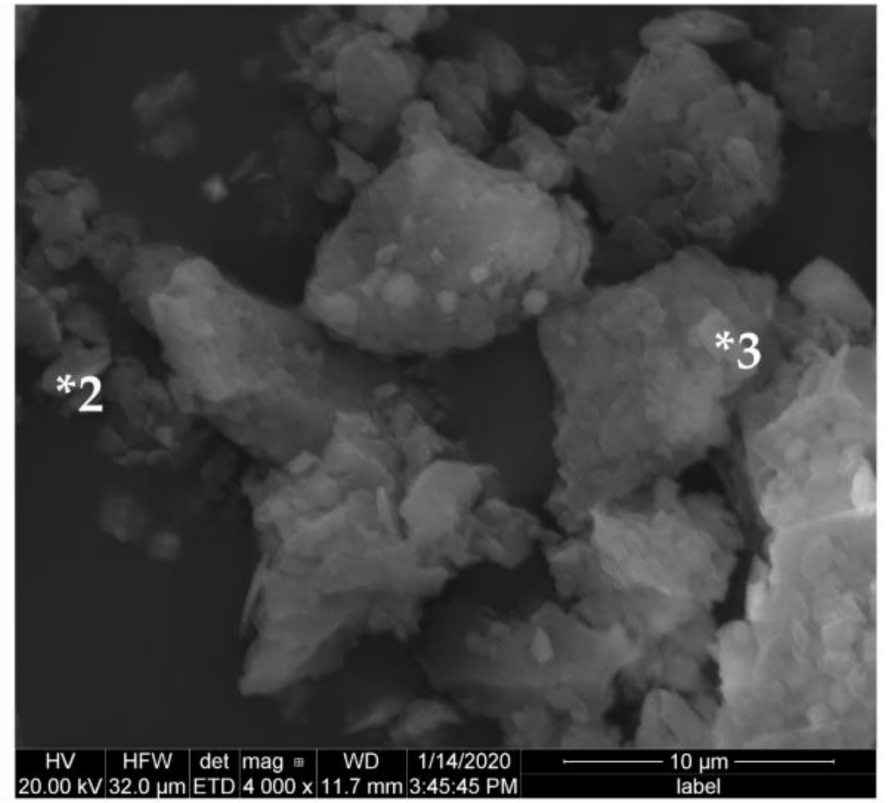

(b)

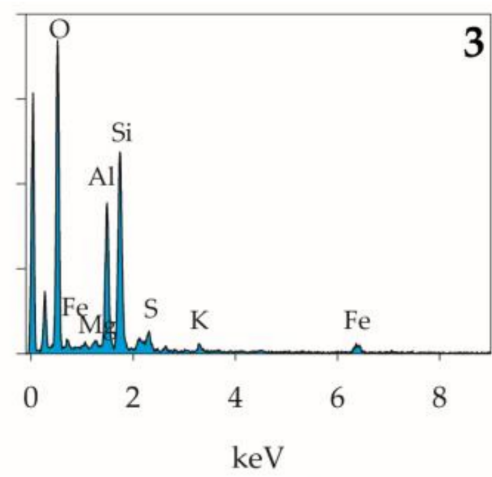

(e)

Figure 8. SEM photomicrographs of pyrite and kaolinite in mangrove soils from a mature mangrove $(\mathrm{RJ}-\mathrm{MM})$ in Rio de Janeiro $(\mathbf{a}, \mathbf{b})$ and their corresponding EDS spectra $(\mathbf{c}-\mathbf{e}),{ }^{*}$ represents the exact surface from where the EDS spectra were obtained). In RJ-MM, the SEM-EDS photomicrographs revealed morphologies of poorly crystalline smooth spherical authigenic pyrite framboids (a). In addition, the SEM-EDS photomicrographs showed the presence of irregularly shaped kaolinite particles (b). 


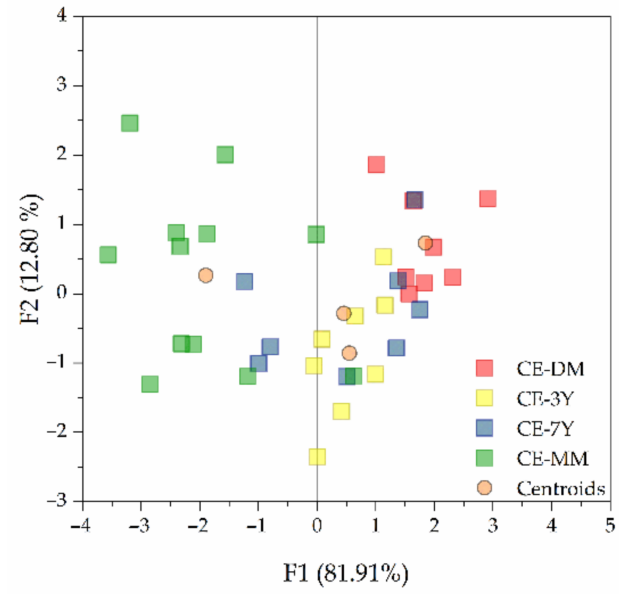

(a)

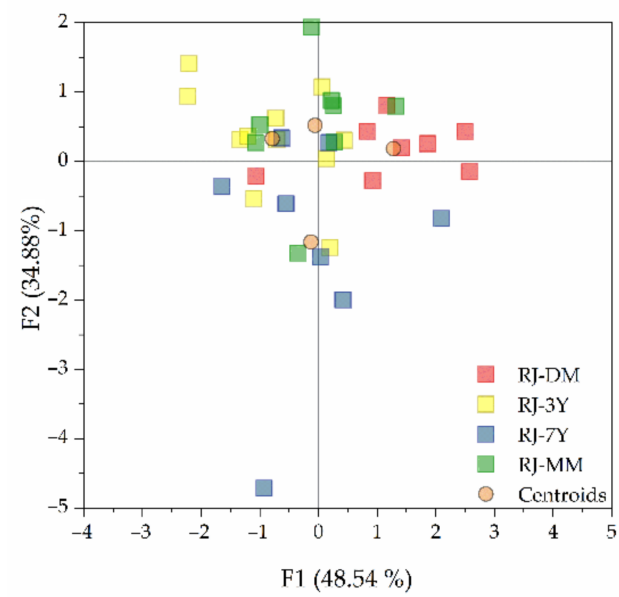

(c)

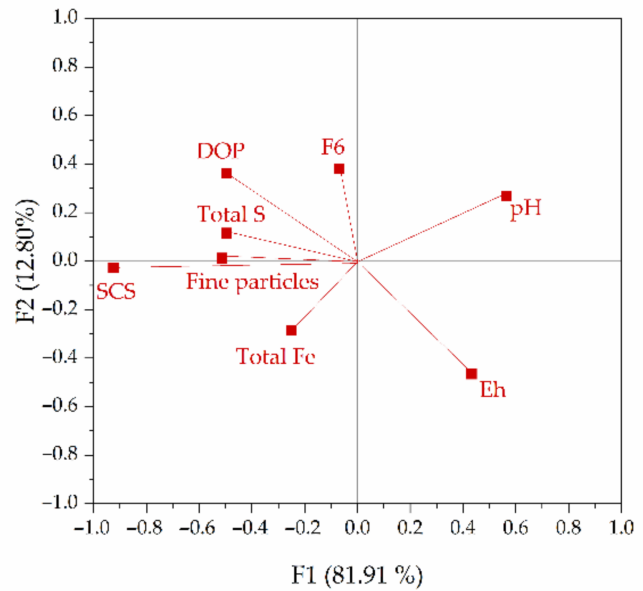

(b)

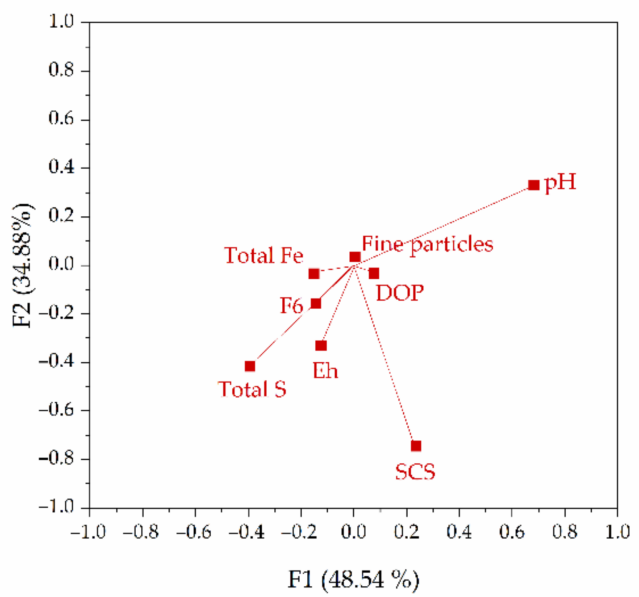

(d)

Figure 9. Discriminant analysis data for the studied soil variables in the Ceará $(\mathbf{a}, \mathbf{b})$ and Rio de Janeiro (c,d) sites. The squares on the right represent the correlations among the soil parameters that compose the two discriminant functions. Fine particles: $\Sigma$ clay and silt; SCS: soil carbon stock; DOP: degree of pyritization.

\section{Discussion}

\subsection{Particle Size Distribution and Soil Carbon Stocks in the Different Replanted Plots}

In the Ceara site, the dominance of sand in all plots is related to the surrounding soils and geological materials (i.e., sedimentary deposits from the Barreiras Formation), mainly with a sandy-clayey texture [40].

However, our results reveal a significant increase in fine particles from CE-DM to CE$7 Y$, with the highest contents observed in CE-MM (Figure 2). This increase in fine particles (clay + silt) with forest development is related to a higher particle trapping capacity by aerial roots, decreasing hydrological energy and favoring deposition $[53,54]$. This increase in fine particles was also significantly correlated to a gradual increase in SCS upon replanting (Figure 3a), which indicates an organic carbon accumulation promoted by an interaction with fine-grained mineral particles (silt and clay). Previous works have suggested that the sorption of organic matter to the surfaces of fine-grained minerals directly controls the accumulation and preservation of soil organic matter in coastal environments. These organic matter-mineral interactions are a product of the high surface areas of the mineral matrix $[55,56]$. This mechanism is corroborated by the discriminant analysis that shows a positive relation between vectors of fine particles and SCS (Figure 9).

On the other hand, in the Rio de Janeiro site, all mangrove soils showed naturally high contents of fine particles (clay and silt; Figure 2b) and SCS (Figure 3b). The absence 
of a gradual rise in fine particles associated with SCS in this site may be related to the presence of invasive species Acrostichum aureum (especially in the degraded and replanted plots). Acrostichum aureum is known for its dense root zone and, thus, for promoting both trapping of mineral particles and high organic matter inputs into soils [37,57]. Moreover, the Guanabara Bay is geographically constrained and marked by low hydrodynamic energies, decreasing dissolved carbon exportation towards the ocean $[58,59]$.

The higher presence of fine particles in all plots in the Rio de Janeiro site also reflects the characteristics of the surrounding soils of the Serra do Mar scarps, which originate from granite-gneiss rocks and are rich in authigenic fine-grained minerals (silt and clay), such as kaolinite, gibbsite, and Fe oxyhydroxides [60]. This environmental context favors clayrich mangrove soils ( $>50 \%)$, which contrast with those in the Ceará coast $[44,61]$. Indeed, XRD results (Figure 6) and SEM micrographs (Figure 8) of mangrove soils from Rio de Janeiro corroborate the higher presence of clay minerals in both degraded and revegetated plots. Furthermore, in Guanabara Bay, the semidiurnal tidal regime, with a range of $0.7 \mathrm{~m}$ (i.e., low hydrodynamic energy), favors fine particle deposition (e.g., clay minerals) and promotes the low export of suspended materials to adjacent areas $[62,63]$. However, in the Rio de Janeiro site a gradual increase of SCS was not observed, with no significant differences between RJ-MM and RJ-DM and higher values at the RJ-7Y plot (Figure 3). In mature mangroves, fauna activity plays a key role in the soil carbon dynamic $[64,65]$. Fauna activity, mainly macro- and mesofauna, acts on organic matter decomposition, firstly promoting the fragmentation of organic matter decreasing the contact area for subsequent decomposition by the microbiota [66]. In addition, fauna activity favors the $\mathrm{O}_{2}$ diffusion in mangrove soils through channels and burrows, which enhances the most energy-efficient aerobic decomposition of organic matter [65]. Indeed, the RJ-MM recorded the higher Eh values (+424 $\pm 197 \mathrm{mV}$; Table 1) among Rio de Janeiro plots.

\subsection{Responses of Fe, C, and S Geochemistry to Revegetation: Implications for Soil Functions}

Fe partitioning indicates evident changes in Fe and $S$ geochemistry as the forest developed in both study sites. In mangrove soils from Ceará, the increase in total Fe contents and low-crystallinity Fe oxyhydroxides in replanted plots (CE-3Y and CE-7Y; Figure 4) favors pyritization, as corroborated by vectors of F6, DOP, and total Fe in replanted and mature mangroves (Figure 9a,b). Additionally, poorly crystalline Fe oxyhydroxides are more susceptible to reductive dissolution, a process coupled to pyritization [67-70]. The effects of a higher availability of Fe (e.g., reactive Fe) or Fe oxyhydroxides favoring pyritization have been widely reported in previous studies [71,72]. Although F6 contents were low in replanted plots compared with CE-MM, a significant increase was observed in DOP compared with the degraded plot (CE-DM; Figure 4c). The recovery of pyritization plays a key role in immobilizing contaminants in mangrove soils [17]. Pyrite is an important trace metal-binding phase within mangrove soils [16,17]; therefore, its presence is directly associated with the regulating pollutant removal service [73].

In addition, higher total Fe and Fe oxyhydroxide contents (within the fine particle fraction) directly affect SCS in replanted plots. This assumption is supported by the positive correlation among vectors of fine particles, total Fe, and SCS shown by the discriminant analysis (Figure 9b). Several recent studies have reported that poorly crystalline Fe oxyhydroxides (e.g., ferrihydrite and lepidocrocite) play an important role in preserving and accumulating soil organic matter in mangrove soils [74]. These works reported the formation of stable complexes between the functional groups in organic matter and those in poorly crystalline Fe oxyhydroxides [75-77]. In fact, a recent study conducted in this revegetated area revealed how the content of organic matter in degraded and newly replanted mangroves depends on organomineral interactions [78], probably with Fe oxyhydroxides.

Furthermore, annual SCS increases in replanted plots in Ceará (Figure 3a) are higher than values reported in other studies along the Brazilian coast, for example in Cananéia (1.9 $\mathrm{Mg} \mathrm{ha}^{-1}$ year $^{-1}$ ) [79] and Ilha Grande (2.0 $\mathrm{Mg} \mathrm{ha}^{-1}$ year $^{-1}$ ) [80]. Our findings also reveal a higher potential for carbon sequestration than the average estimates for man- 
groves reported by previous studies at different locations; e.g., $2.3 \mathrm{Mg} \mathrm{ha}^{-1}$ year $^{-1}$ [81], 1.4 $\mathrm{Mg} \mathrm{ha}^{-1}$ year $^{-1}$ [82], $2.0 \mathrm{Mg} \mathrm{ha}^{-1}$ year $^{-1}$ [83], and 3.0 $\mathrm{Mg} \mathrm{ha}^{-1}$ year ${ }^{-1}$ [84]. Thus, SCS values in the Ceará replanted plots provide strong evidence for the recovery of geochemical processes and its impact on $\mathrm{Fe}, \mathrm{S}$, and $\mathrm{C}$ dynamics.

Similarly, in mangrove soils from Rio de Janeiro, an increase in Fe contents was observed as plants developed, mainly related to increases in low-crystallinity Fe oxyhydroxide (i.e., F3 + F4) and pyrite (i.e., F6; Figure 4b) contents. Despite the absence of significant differences in DOP values (Figure 4d), the higher pyritization in Rio de Janeiro $(\sim 50 \%)$ is probably related to the higher contents of reactive Fe available for reaction with dissolved sulfide $\left(\mathrm{HS}^{-}\right)$[85]. The high contents of pyrite-associated Fe (i.e., F6) indicate that sulfate reduction is the main anaerobic metabolism related to soil organic matter degradation at Rio de Janeiro $[8,39,86]$. In fact, in mangrove soils, microbial-mediated sulfate reduction is widely reported as a significant respiration pathway that favors soil organic matter accumulation [8,15]. Previous studies have shown that the high availability of reactive Fe forms favors pyritization and enhances soil organic matter contents $[33,48,87]$.

Since sulfate reduction has a lower energy yield compared to other respiration pathways (e.g., reduction of $\mathrm{NO}_{3}{ }^{-}, \mathrm{Mn}^{3+}$, and $\mathrm{Fe}^{3+}$ ) [12,15], the rate of decomposition is considerably lower than the rate of organic matter input, leading to carbon-rich soils [77]. Furthermore, mangrove soils from Rio de Janeiro are mostly composed of clay minerals (e.g., kaolinite; Figures 6 and 8), which have been reported to physically protect soil organic matter against microbial decomposition $[76,88]$. This physical protection and preservation of organic matter explain the high SCS in RJ-DM. In fact, the role of phyllosilicates in preserving soil organic matter has been previously reported and related to the establishment of organomineral associations [89]. In this case, phyllosilicates, such as kaolinite, and iron oxyhydroxides provide surface charges (both permanent and variable) and high-surface areas ( $>>$ in Fe oxyhydroxides) that contribute to organic matter adsorption (e.g., innersphere, outersphere, and H-bonding), resulting in its physical protection against decomposition [90]. Therefore, these mechanisms may be responsible for the high SCS recorded in the Rio de Janeiro site. In fact, the SCS in RJ-7Y $\left(59.6 \pm 15.2 \mathrm{Kg} \mathrm{m}^{-2}\right.$; Figure $3 \mathrm{~b}$ ) was higher than the mean SCS reported for mangrove soils (up to $100 \mathrm{~cm}$ depth) in 15-year-old (48.3 $\left.\mathrm{Kg} \mathrm{m}^{-2}\right)$ [91] and 20-year-old replanted plots $\left(25.8 \mathrm{Kg} \mathrm{m}^{-2}\right)$ [92].

In the Rio de Janeiro site, a combination of geoenvironmental settings (i.e., geology, geomorphology) and biological factors has led to the recovery of soil geochemical processes (e.g., sulfate reduction) and of SCS, positively impacting the soil functions of metal immobilization and carbon sequestration.

\section{Concluding Remarks}

Our findings suggest that mangrove reforestation initiatives are an effective strategy for recovering soil functions (i.e., carbon sequestration and metal retention) and their related ecosystem services (i.e., climate regulation and filtering of pollutants). Although soil response was variable in both study sites, increases in reactive Fe, pyrite, DOP, and SCS were observed in mangrove soils after replanting. The recovery of key soil processes (related to $\mathrm{Fe}, \mathrm{S}$, and C) directly affected the ability of these replanted mangroves to accumulate organic matter and potentially control bioavailability of pollutants (e.g., trace metals; Figure 10). In this sense, specific protocols for mangrove restoration initiatives [93-95] should consider the variability of factors such as soil texture, climate conditions, and geological surroundings, since these features directly affect the recovery of soil functions. 


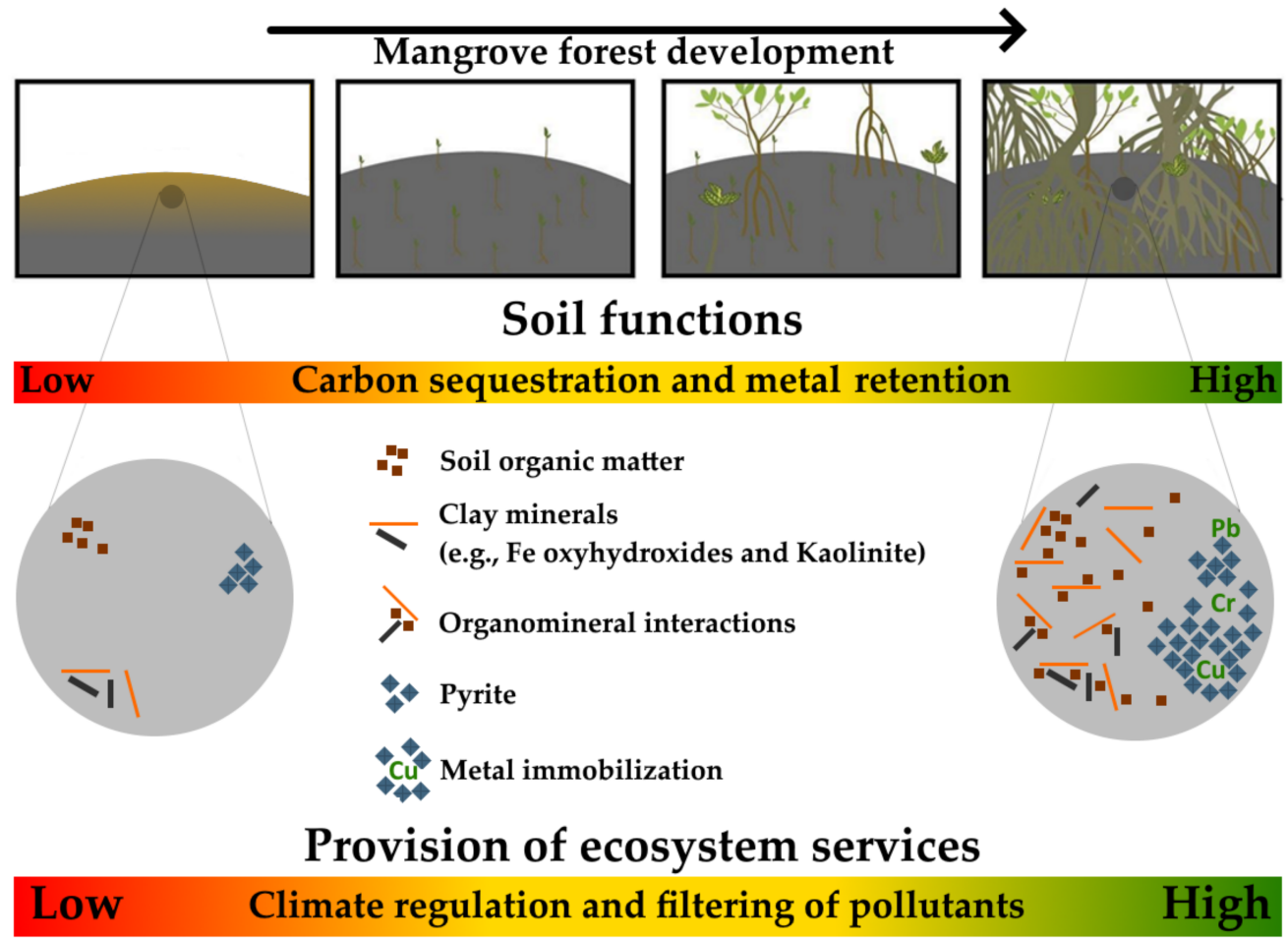

Figure 10. Schematic summary showing a conceptual model for the recovery of the studied soil functions upon mangrove revegetation. The development of mangrove forests led to an increase in organic matter input from vegetation and fine particle trapping (e.g., phyllosilicates and $\mathrm{Fe}$ oxyhydroxides), which contributed to increasing SCS. An increase in reactive Fe favors pyritization and, thus, the potential for pollutant immobilization. The recovery of these soil functions shows high potential for restoring the ecosystem services of climate regulation and filtering of pollutants.

Understanding how the recovery of soil functions impacts the restoration of ecosystem services in replanted mangroves may help guide future restoration programs as a naturebased solution for achieving net-zero emission targets.

Author Contributions: T.O.F., G.N.N., D.J.R., L.C.Z.J. and H.M.Q. designed the field study. L.C.Z.J., D.J.R., H.M.Q., Y.D. and G.N.N. collected samples and performed laboratory analyses. L.C.Z.J. and H.M.Q. analyzed data. L.C.Z.J., H.M.Q., T.O.F., G.N.N., D.J.R. and X.L.O. wrote the paper. All authors participated in editing the paper. All authors have read and agreed to the published version of the manuscript.

Funding: This research was funded by the Coordenação de Aperfeiçoamento de Pessoal de Nível Superior (Finance Code 001), National Council for Scientific and Technological Development (CNPQ; grant numbers 305996/2018-5 and 430010/2018-4 to TOF and 409593/2018-4 to GNN), the São Paulo Research Foundation (FAPESP; grant number 2021/00221-3 to HMQ), and the Fundação Carlos Chagas Filho de Amparo à Pesquisa do Estado do Rio de Janeiro (grant number E-26/202.757/2019 to GNN).

Institutional Review Board Statement: Not applicable.

Informed Consent Statement: Not applicable.

Data Availability Statement: Not applicable.

Acknowledgments: The authors would like to acknowledge the Coordenação de Aperfeiçoamento de Pessoal de Nível Superior (CAPES), National Council for Scientific and Technological Development, São Paulo Research Foundation, and the Fundação Carlos Chagas Filho de Amparo à Pesquisa do Estado do Rio de Janeiro for their funding and scholarships.

Conflicts of Interest: The authors declare no conflict of interest. 


\section{References}

1. Costanza, R.; de Groot, R.; Sutton, P.; van der Ploeg, S.; Anderson, S.J.; Kubiszewski, I.; Farber, S.; Turner, R.K. Changes in the global value of ecosystem services. Glob. Environ. Chang. 2014, 26, 152-158. [CrossRef]

2. Costanza, R.; D'Arge, R.; de Groot, R.; Farber, S.; Grasso, M.; Hannon, B.; Limburg, K.; Naeem, S.; O’Neill, R.V.; Paruelo, J.; et al. The value of the world's ecosystem services and natural capital. Nature 1997, 387, 253-260. [CrossRef]

3. Wang, M.; Cao, W.; Jiang, C.; Yan, Y.; Guan, Q. Potential ecosystem service values of mangrove forests in southeastern China using high-resolution satellite data. Estuar. Coast. Shelf Sci. 2018, 209, 30-40. [CrossRef]

4. Jardine, S.L.; Siikamäki, J.V. A global predictive model of carbon in mangrove soils. Environ. Res. Lett. 2014, 9, 104013. [CrossRef]

5. Adhikari, K.; Hartemink, A.E. Linking soils to ecosystem services-A global review. Geoderma 2016, 262, 101-111. [CrossRef]

6. Tripathi, R.; Shukla, A.; Shahid, M.; Nayak, D.; Puree, C.; Mohanty, S.; Raja, R.; Lal, B.; Gautam, P.; Bhattacharyya, P.; et al. Soil quality in mangrove ecosystem deteriorates due to rice cultivation. Ecol. Eng. 2016, 90, 163-169. [CrossRef]

7. Faridah-Hanum, I.; Yusoff, F.M.; Fitrianto, A.; Ainuddin, N.A.; Gandaseca, S.; Zaiton, S.; Norizah, K.; Nurhidayu, S.; Roslan, M.K.; Hakeem, K.R.; et al. Development of a comprehensive mangrove quality index (MQI) in Matang Mangrove: Assessing mangrove ecosystem health. Ecol. Indic. 2019, 102, 103-117. [CrossRef]

8. Kristensen, E.; Bouillon, S.; Dittmar, T.; Marchand, C. Organic carbon dynamics in mangrove ecosystems: A review. Aquat. Bot. 2008, 89, 201-219. [CrossRef]

9. Otero, X.L.; Macías, F. Biogeochemistry and Pedogenetic Process in Saltmarsh and Mangrove Systems, 1st ed.; Nova Science Publishers: Hauppauge, NY, USA, 2010; ISBN 978-1-61728-269-0.

10. de Sousa, R.O.; Vahl, L.C.; Otero, X.L. Química de solos alagados. In Química e Mineralogia do Solo-Parte II-Aplicações; Sociedade Brasileira de Ciência do Solo: Viçosa, Brazil, 2016; pp. 485-528.

11. Lovley, D.R.; Holmes, D.E.; Nevin, K.P. Dissimilatory Fe(III) and Mn(IV) Reduction. In Advances in Microbial Physiology; Academic Press: London, UK, 2004; Volume 49, pp. 219-286. ISBN 9780120277490.

12. Alongi, D.M.; Tirendi, F.; Dixon, P.; Trott, L.A.; Brunskill, G.J. Mineralization of Organic Matter in Intertidal Sediments of a Tropical Semi-enclosed Delta. Estuar. Coast. Shelf Sci. 1999, 48, 451-467. [CrossRef]

13. Chapelle, F.H.; Lovley, D.R. Competitive Exclusion of Sulfate Reduction by Fe(lll)-Reducing Bacteria: A Mechanism for Producing Discrete Zones of High-Iron Ground Water. Ground Water 1992, 30, 29-36. [CrossRef]

14. Ferreira, T.O.; Nóbrega, G.N.; Queiroz, H.M.; de Souza Júnior, V.S.; Barcellos, D.; Ferreira, A.D.; Otero, X.L. Windsock behavior: Climatic control on iron biogeochemistry in tropical mangroves. Biogeochemistry 2021, 156, 437-452. [CrossRef]

15. Alongi, D.M.; Wattayakorn, G.; Pfitzner, J.; Tirendi, F.; Zagorskis, I.; Brunskill, G.; Davidson, A.; Clough, B. Organic carbon accumulation and metabolic pathways in sediments of mangrove forests in southern Thailand. Mar. Geol. 2001, 179, 85-103. [CrossRef]

16. Ye, S.; Laws, E.A.; Wu, Q.; Zhong, S.; Ding, X.; Zhao, G.; Gong, S. Pyritization of trace metals in estuarine sediments and the controlling factors: A case in Jiaojiang Estuary of Zhejiang Province, China. Environ. Earth Sci. 2010, 61, 973-982. [CrossRef]

17. Machado, W.; Borrelli, N.L.; Ferreira, T.O.; Marques, A.G.B.; Osterrieth, M.; Guizan, C. Trace metal pyritization variability in response to mangrove soil aerobic and anaerobic oxidation processes. Mar. Pollut. Bull. 2014, 79, 365-370. [CrossRef]

18. Huerta-Diaz, M.A.; Morse, J.W. Pyritization of trace metals in anoxic marine sediments. Geochim. Cosmochim. Acta 1992, 56, 2681-2702. [CrossRef]

19. Santos Garcia, J.; Sershen; França, M.G.C. Mangrove Assisted Remediation and Ecosystem Services. In Handbook of Assisted and Amendment: Enhanced Sustainable Remediation Technology; Wiley: Hoboken, NJ, USA, 2021; pp. 535-556.

20. Kelleway, J.J.; Saintilan, N.; Macreadie, P.I.; Baldock, J.A.; Ralph, P.J. Sediment and carbon deposition vary among vegetation assemblages in a coastal salt marsh. Biogeosciences 2017, 14, 3763-3779. [CrossRef]

21. Sinclair, M.; Vishnu Sagar, M.K.; Knudsen, C.; Sabu, J.; Ghermandi, A. Economic appraisal of ecosystem services and restoration scenarios in a tropical coastal Ramsar wetland in India. Ecosyst. Serv. 2021, 47, 101236. [CrossRef]

22. Sannigrahi, S.; Zhang, Q.; Pilla, F.; Joshi, P.K.; Basu, B.; Keesstra, S.; Roy, P.S.; Wang, Y.; Sutton, P.C.; Chakraborti, S.; et al. Responses of ecosystem services to natural and anthropogenic forcings: A spatial regression based assessment in the world's largest mangrove ecosystem. Sci. Total Environ. 2020, 715, 137004. [CrossRef]

23. Ellison, A.M.; Felson, A.J.; Friess, D.A. Mangrove Rehabilitation and Restoration as Experimental Adaptive Management. Front. Mar. Sci. 2020, 7, 327. [CrossRef]

24. Van Oudenhoven, A.P.E.; Siahainenia, A.J.; Sualia, I.; Tonneijck, F.H.; van der Ploeg, S.; de Groot, R.S.; Alkemade, R.; Leemans, R. Effects of different management regimes on mangrove ecosystem services in Java, Indonesia. Ocean Coast. Manag. 2015, 116, 353-367. [CrossRef]

25. Malik, A.; Fensholt, R.; Mertz, O. Mangrove exploitation effects on biodiversity and ecosystem services. Biodivers. Conserv. 2015, 24, 3543-3557. [CrossRef]

26. Ahmed, N.; Cheung, W.W.L.; Thompson, S.; Glaser, M. Solutions to blue carbon emissions: Shrimp cultivation, mangrove deforestation and climate change in coastal Bangladesh. Mar. Policy 2017, 82, 68-75. [CrossRef]

27. Chowdhury, R.R.; Uchida, E.; Chen, L.; Osorio, V.; Yoder, L. Anthropogenic Drivers of Mangrove Loss: Geographic Patterns and Implications for Livelihoods. In Mangrove Ecosystems: A Global Biogeographic Perspective; Springer: Berlin/Heidelberg, Germany, 2017; ISBN 9783319622064. 
28. Kauffman, J.B.; Bernardino, A.F.; Ferreira, T.O.; Bolton, N.W.; de Gomes, L.E.O.; Nobrega, G.N. Shrimp ponds lead to massive loss of soil carbon and greenhouse gas emissions in northeastern Brazilian mangroves. Ecol. Evol. 2018, 8, 5530-5540. [CrossRef] [PubMed]

29. Otero, X.L.; Méndez, A.; Nóbrega, G.N.; Ferreira, T.O.; Santiso-Taboada, M.J.; Meléndez, W.; Macías, F. High fragility of the soil organic C pools in mangrove forests. Mar. Pollut. Bull. 2017, 119, 460-464. [CrossRef] [PubMed]

30. Barros, F.P.; Santos, D.M.; de Andrade, N.A.; de Freitas, A.L.; Neto, A.C.; Bezerra, D.H.S.; de Leite, M.J.H.; de Brilhante, J.C.A. The natural ecomuseum of mangrove: Educational and reforestation actions/O ecomuseu natural do mangue: Ações educativas e de reflorestamento. Brazilian Appl. Sci. Rev. 2021, 5, 482-497. [CrossRef]

31. ICMBio. Atlas dos Manguezais do Brasil, 1st ed.; Instituto Chico Mendes de Conservação da Biodiversidade: Brasília, Brazil, 2018; ISBN 9788561842758.

32. De Fonseca, S.M.; Drummond, J.A. Reflorestamento de manguezais e o valor de resgate para o seqüestro de carbono atmosférico. História Ciências Saúde-Manguinhos 2003, 10, 1071-1081. [CrossRef]

33. Nóbrega, G.N.; Ferreira, T.O.; Siqueira Neto, M.; Queiroz, H.M.; Artur, A.G.; Mendonça, E.D.S.; Silva, E.D.O.; Otero, X.L. Edaphic factors controlling summer (rainy season) greenhouse gas emissions $\left(\mathrm{CO}_{2}\right.$ and $\left.\mathrm{CH}_{4}\right)$ from semiarid mangrove soils (NE-Brazil). Sci. Total Environ. 2016, 542, 685-693. [CrossRef]

34. Fries, A.S.; Coimbra, J.P.; Nemazie, D.A.; Summers, R.M.; Azevedo, J.P.S.; Filoso, S.; Newton, M.; Gelli, G.; de Oliveira, R.C.N.; Pessoa, M.A.R.; et al. Guanabara Bay ecosystem health report card: Science, management, and governance implications. Reg. Stud. Mar. Sci. 2019, 25, 100474. [CrossRef]

35. Soares, M.L.G.; Silva, C.M.G., Jr.; Cavalcanti, V.F.; Almeida, P.M.M.; Monteiro, A.S.; Chaves, F.O.; Duque Estrada, G.C.; Barbosa, B. Regeneração de floresta de mangue atingifa por óleo na baía de Guanabara (Rio de Janeiro, Brasil): Resultados de 5 anos de monitoramento. Geochim. Bras. 2006, 20, 54-77. [CrossRef]

36. Borges, A.C.; Dias, J.C.; Machado, W.; Patchineelam, S.R.; Sella, S.M. Distribuição espacial de ferro, cobre e chumbo em sedimentos de manguezal em um gradiente de degradação na Baía de Guanabara (Estado do Rio de Janeiro). Quim. Nova 2007, 30, 66-69. [CrossRef]

37. Medina, E.; Cuevas, E.; Popp, M.; Lugo, A.E. Soil Salinity, Sun Exposure, and Growth of Acrostichum aureum, the Mangrove Fern. Bot. Gaz. 1990, 151, 41-49. [CrossRef]

38. Alvares, C.A.; Stape, J.L.; Sentelhas, P.C.; De Moraes Gonçalves, J.L.; Sparovek, G. Köppen's climate classification map for Brazil. Meteorol. Zeitschrift 2013, 22, 711-728. [CrossRef]

39. Nóbrega, G.N.; Ferreira, T.O.; Romero, R.E.; Marques, A.G.B.; Otero, X.L. Iron and sulfur geochemistry in semi-arid mangrove soils (Ceará, Brazil) in relation to seasonal changes and shrimp farming effluents. Environ. Monit. Assess. 2013, 185, 7393-7407. [CrossRef] [PubMed]

40. Behling, H.; da Costa, M.L. Mineralogy, geochemistry, and palynology of modern and late Tertiary mangrove deposits in the Barreiras Formation of Mosqueiro Island, northeastern Pará state, eastern Amazonia. J. S. Am. Earth Sci. 2004, 17, $285-295$. [CrossRef]

41. Bigarella, J.J. Estrutura e Origem das Paisagens Tropicais e Subtropicais, 3rd ed.; Editora da UFSC: Florianópolis, Brazil, 2003; ISBN 8532802664.

42. Maia, L.P.; de Lacerda, L.D.; Monteiro, L.H.U.; Souza, G.M. Estudo das Áreas de Manguezais do Nordeste do Brasil-Avaliação das Áreas de Manguezais dos Estados do Piauí, Ceará, Rio Grande do Norte, Paraíba e Pernambuco, 1st ed.; Instituo de Ciências do Mar Sociedade Internacional Para Ecossistemas de Manguezal-ISME-BR, Universidade Federal do Ceará: Fortaleza, Brazil, 2005.

43. Ferreira, T.O.; Nóbrega, G.N.; Albuquerque, A.G.B.M.B.M.; Sartor, L.R.; Gomes, I.S.; Artur, A.G.; Otero, X.L. Pyrite as a proxy for the identification of former coastal lagoons in semiarid NE Brazil. Geo-Marine Lett. 2015, 35, 355-366. [CrossRef]

44. Vieira, B.C.; Salgado, A.A.R.; Santos, L.J.C. Landscapes and Landforms of Brazil. In World Geomorphological Landscapes; Vieira, B.C., Salgado, A.A.R., Santos, L.J.C., Eds.; Springer: Dordrecht, The Netherlands, 2015; ISBN 978-94-017-8022-3.

45. Kjerfve, B.; Ribeiro, C.H.A.; Dias, G.T.M.; Filippo, A.M.; Da Silva Quaresma, V. Oceanographic characteristics of an impacted coastal bay: Baía de Guanabara, Rio de Janeiro, Brazil. Cont. Shelf Res. 1997, 17, 1609-1643. [CrossRef]

46. Gee, G.W.; Bauder, J.W. Particle-size analysis. In Methods of Soil Analysis: Part 1-Physical and Mineralogical Methods; Soil Science Society of America, American Society of Agronomy: Madison, WI, USA, 1986; pp. 383-411.

47. Howard, J.; Hoyt, S.; Isensee, K.; Telszewski, M.; Pidgeon, E.; Telszewski, M. Coastal Blue Carbon: Methods for Assessing Carbon Stocks and Emissions Factors in Mangroves, Tidal Salt Marshes, and Seagrasses; Conservation International, Intergovernmental Oceanographic Commission of UNESCO, International Union for Conservation of Nature: Arlington, VA, USA, 2014; Volume 1, ISBN 9782831717623

48. Ferreira, T.O.; Otero, X.L.; Vidal-Torrado, P.; Macías, F. Redox Processes in Mangrove Soils under Rhizophora mangle in Relation to Different Environmental Conditions. Soil Sci. Soc. Am. J. 2007, 71, 484-491. [CrossRef]

49. Otero, X.L.; Ferreira, T.O.; Huerta-Díaz, M.A.; Partiti, C.S.M.; Souza, V.; Vidal-Torrado, P.; Macías, F. Geochemistry of iron and manganese in soils and sediments of a mangrove system, Island of Pai Matos (Cananeia-SP, Brazil). Geoderma 2009, 148, 318-335. [CrossRef]

50. Otero, X.L.; Lucheta, A.R.; Ferreira, T.O.; Huerta-Díaz, M.A.; Lambais, M.R. Archaeal diversity and the extent of iron and manganese pyritization in sediments from a tropical mangrove creek (Cardoso Island, Brazil). Estuar. Coast. Shelf Sci. 2014, 146, 1-13. [CrossRef] 
51. Siregar, A.; Kleber, M.; Mikutta, R.; Jahn, R. Sodium hypochlorite oxidation reduces soil organic matter concentrations without affecting inorganic soil constituents. Eur. J. Soil Sci. 2005, 56, 481-490. [CrossRef]

52. Reimann, C.; Filzmoser, P.; Garrett, R.G.; Dutter, R. Statistical Data Analysis Explained; John Wiley \& Sons, Ltd.: Chichester, UK, 2008; ISBN 9780470987605.

53. Krauss, K.W.; Mckee, K.L.; Lovelock, C.E.; Cahoon, D.R.; Saintilan, N.; Reef, R.; Chen, L. How mangrove forests adjust to rising sea level. New Phytol. 2014, 202, 19-34. [CrossRef] [PubMed]

54. Perry, C.T.; Berkeley, A. Intertidal substrate modification as a result of mangrove planting: Impacts of introduced mangrove species on sediment microfacies characteristics. Estuar. Coast. Shelf Sci. 2009, 81, 225-237. [CrossRef]

55. Macreadie, P.I.; Anton, A.; Raven, J.A.; Beaumont, N.; Connolly, R.M.; Friess, D.A.; Kelleway, J.J.; Kennedy, H.; Kuwae, T.; Lavery, P.S.; et al. The future of Blue Carbon science. Nat. Commun. 2019, 10, 3998. [CrossRef] [PubMed]

56. Keil, R.G.; Hedges, J.I. Sorption of organic matter to mineral surfaces and the preservation of organic matter in coastal marine sediments. Chem. Geol. 1993, 107, 385-388. [CrossRef]

57. Xin, K.; Yan, K.; Gao, C.; Li, Z. Carbon storage and its influencing factors in Hainan Dongzhangang mangrove wetlands. Mar. Freshw. Res. 2018, 69, 771. [CrossRef]

58. Ezcurra, P.; Ezcurra, E.; Garcillán, P.P.; Costa, M.T.; Aburto-Oropeza, O. Coastal landforms and accumulation of mangrove peat increase carbon sequestration and storage. Proc. Natl. Acad. Sci. USA 2016, 113, 4404-4409. [CrossRef]

59. Twilley, R.R.; Rovai, A.S.; Riul, P. Coastal morphology explains global blue carbon distributions. Front. Ecol. Environ. 2018, 16, 503-508. [CrossRef]

60. Fernandes, N.F.; Tupinambá, M.; Mello, C.L.; de Peixoto, M.N.O. Rio de Janeiro: A Metropolis Between Granite-Gneiss Massifs. In Geomorphological Landscapes of the World; Springer: Dordrecht, The Netherlands, 2009; pp. 89-100.

61. Lacerda, W.A. Shear strength of soils derived from the weathering of granite and gneiss in Brazil. Geol. Soc. London, Eng. Geol. Spec. Publ. 2010, 23, 167-182. [CrossRef]

62. Ergin, M.; Bodur, M.N. Silt/clay fractionation in surficial Marmara sediments: Implication for water movement and sediment transport paths in a semi-enclosed and two-layered flow system (northeastern Mediterranean Sea). Geo-Marine Lett. 1998, 18, 225-233. [CrossRef]

63. Guézennec, L.; Lafite, R.; Dupont, J.-P.; Meyer, R.; Boust, D.; Guezennec, L. Hydrodynamics of Suspended Particulate Matter in the Tidal Freshwater Zone of a Macrotidal Estuary (The Seine Estuary, France). Estuaries 1999, 22, 717. [CrossRef]

64. Berezina, N.A.; Gubelit, Y.I.; Polyak, Y.M.; Sharov, A.N.; Kudryavtseva, V.A.; Lubimtsev, V.A.; Petukhov, V.A.; Shigaeva, T.D. An integrated approach to the assessment of the eastern Gulf of Finland health: A case study of coastal habitats. J. Mar. Syst. 2017, 171, 159-171. [CrossRef]

65. Ferreira, T.O.; Otero, X.L.; Vidal-Torrado, P.; Macías, F. Effects of bioturbation by root and crab activity on iron and sulfur biogeochemistry in mangrove substrate. Geoderma 2007, 142, 36-46. [CrossRef]

66. Friesen, S.D.; Dunn, C.; Freeman, C. Decomposition as a regulator of carbon accretion in mangroves: A review. Ecol. Eng. 2018, 114, 173-178. [CrossRef]

67. Winkler, P.; Kaiser, K.; Thompson, A.; Kalbitz, K.; Fiedler, S.; Jahn, R. Contrasting evolution of iron phase composition in soils exposed to redox fluctuations. Geochim. Cosmochim. Acta 2018, 235, 89-102. [CrossRef]

68. Bonneville, S.; Van Cappellen, P.; Behrends, T. Microbial reduction of iron(III) oxyhydroxides: Effects of mineral solubility and availability. Chem. Geol. 2004, 212, 255-268. [CrossRef]

69. Larsen, O.; Postma, D. Kinetics of reductive bulk dissolution of lepidocrocite, ferrihydrite, and goethite. Geochim. Cosmochim. Acta 2001, 65, 1367-1379. [CrossRef]

70. Lin, S.; Morse, J. Sulfate reduction and iron sulfide mineral formation in Gulf of Mexico anoxic sediments. Am. J. Sci. 1991, 291, 55-89. [CrossRef]

71. Wang, D.Y.; Zhu, M.X.; Sun, C.H.; Ma, K.; Sun, W.X.; Zhang, X.R.; Sun, Z.L. Geochemistry of iron and sulfur in the Holocene marine sediments under contrasting depositional settings, with caveats for applications of paleoredox proxies. J. Mar. Syst. 2021, 220, 103572. [CrossRef]

72. Wijsman, J.W.M.; Middelburg, J.J.; Heip, C.H.R. Reactive iron in Black Sea sediments: Implications for iron cycling. Mar. Geol. 2001, 172, 167-180. [CrossRef]

73. Thanh-Nho, N.; Marchand, C.; Strady, E.; Vinh, T.-V.; Nhu-Trang, T.-T. Metals geochemistry and ecological risk assessment in a tropical mangrove (Can Gio, Vietnam). Chemosphere 2019, 219, 365-382. [CrossRef]

74. Rasmussen, C.; Heckman, K.; Wieder, W.R.; Keiluweit, M.; Lawrence, C.R.; Asefaw, A.; Blankinship, J.C.; Crow, S.E.; Druhan, J.L.; Hicks, C.E.; et al. Beyond clay: Towards an improved set of variables for predicting soil organic matter content. Biogeochemistry 2018, 137, 297-306. [CrossRef]

75. Wang, P.; Wang, J.; Zhang, H.; Dong, Y.; Zhang, Y. The role of iron oxides in the preservation of soil organic matter under long-term fertilization. J. Soils Sediments 2019, 19, 588-598. [CrossRef]

76. Kida, M.; Fujitake, N. Organic Carbon Stabilization Mechanisms in Mangrove Soils: A Review. Forests 2020, 11, 981. [CrossRef]

77. Kim, J.; Lee, J.; Yang, Y.; Yun, J.; Ding, W.; Yuan, J.; Khim, J.S.; Kwon, B.O.; Kang, H. Microbial decomposition of soil organic matter determined by edaphic characteristics of mangrove forests in East Asia. Sci. Total Environ. 2021, 763, 142972. [CrossRef]

78. Jimenez, L.C.Z.; Queiroz, H.M.; Otero, L.; Nuto, G. Soil Organic Matter Responses to Mangrove Restoration: A Replanting Experience in Northeast Brazil. Int. J. Environ. Res. Public Health 2021, 18, 8981. [CrossRef] 
79. Sanders, C.J.; Smoak, J.M.; Naidu, A.S.; Araripe, D.R.; Sanders, L.M.; Patchineelam, S.R. Mangrove forest sedimentation and its reference to sea level rise, Cananeia, Brazil. Environ. Earth Sci. 2010, 60, 1291-1301. [CrossRef]

80. Sanders, C.J.; Smoak, J.M.; Naidu, A.S.; Patchineelam, S.R. Recent Sediment Accumulation in a Mangrove Forest and Its Relevance to Local Sea-Level Rise (Ilha Grande, Brazil). J. Coast. Res. 2008, 242, 533-536. [CrossRef]

81. Mcleod, E.; Chmura, G.L.; Bouillon, S.; Salm, R.; Björk, M.; Duarte, C.M.; Lovelock, C.E.; Schlesinger, W.H.; Silliman, B.R. A blueprint for blue carbon: Toward an improved understanding of the role of vegetated coastal habitats in sequestering $\mathrm{CO}_{2}$. Front. Ecol. Environ. 2011, 9, 552-560. [CrossRef]

82. Duarte, C.M.; Middelburg, J.J.; Caraco, N. Major role of marine vegetation on the oceanic carbon cycle. Biogeosciences 2005, 2, 1-8. [CrossRef]

83. Chmura, G.L.; Anisfeld, S.C.; Cahoon, D.R.; Lynch, J.C. Global carbon sequestration in tidal, saline wetland soils. Global Biogeochem. Cycles 2003, 17, 1111. [CrossRef]

84. Bouillon, S.; Borges, A.V.; Castañeda-Moya, E.; Diele, K.; Dittmar, T.; Duke, N.C.; Kristensen, E.; Lee, S.Y.; Marchand, C.; Middelburg, J.J.; et al. Mangrove production and carbon sinks: A revision of global budget estimates. Glob. Biogeochem. Cycles 2008, 22, GB2013. [CrossRef]

85. Raiswell, R.; Canfield, D.E.; Berner, R.A. A comparison of iron extraction methods for the determination of degree of pyritisation and the recognition of iron-limited pyrite formation. Chem. Geol. 1994, 111, 101-110. [CrossRef]

86. Howarth, R.W. The ecological significance of sulfur in the energy dynamics of salt marsh and coastal marine sediments. Biogeochemistry 1984, 1, 5-27. [CrossRef]

87. Brodersen, K.E.; Trevathan-Tackett, S.M.; Nielsen, D.A.; Connolly, R.M.; Lovelock, C.E.; Atwood, T.B.; Macreadie, P.I. Oxygen consumption and sulfate reduction in vegetated coastal habitats: Effects of physical disturbance. Front. Mar. Sci. $2019,6,14$. [CrossRef]

88. Xiong, Y.; Liao, B.; Proffitt, E.; Guan, W.; Sun, Y.; Wang, F.; Liu, X. Soil carbon storage in mangroves is primarily controlled by soil properties: A study at Dongzhai Bay, China. Sci. Total Environ. 2018, 619-620, 1226-1235. [CrossRef]

89. Kleber, M.; Eusterhues, K.; Keiluweit, M.; Mikutta, C.; Mikutta, R.; Nico, P.S. Mineral-Organic Associations: Formation, Properties, and Relevance in Soil Environments. Adv. Agron. 2015, 130, 1-140. [CrossRef]

90. Sarkar, B.; Singh, M.; Mandal, S. Clay Minerals-Organic Matter Interactions in Relation to Carbon Stabilization in Soils. In The Future of Soil Carbon; Academic Press: London, UK, 2018; ISBN 9780128116876.

91. Adame, M.F.; Zakaria, R.M.; Fry, B.; Chong, V.C.; Then, Y.H.A.; Brown, C.J.; Lee, S.Y. Loss and recovery of carbon and nitrogen after mangrove clearing. Ocean Coast. Manag. 2018, 161, 117-126. [CrossRef]

92. Lunstrum, A.; Chen, L. Soil carbon stocks and accumulation in young mangrove forests. Soil Biol. Biochem. 2014, 75, 223-232. [CrossRef]

93. Kairo, J.G.; Mangora, M.M. Guidelines on Mangrove Ecosystem Restoration for the Western Indian Ocean Region; United Nations Environment: Nairobi, Kenya, 2020.

94. Amarasinghe, M.; Vidanage, S. Best Practice Guidelines on Restoration of Mangroves in Tsunami Affected Areas; The World Conservation Union (IUCN): Colombo, Sri Lanka, 2007.

95. Dawson, B.; Spannagle, M. Clean Development Mechanism (Cdm). Complet. Guid. to Clim. Chang. 2020, 2-278. [CrossRef] 